\title{
Funding Immigrant Organizations: Suburban Free Riding and Local Civic Presence ${ }^{1}$
}

\author{
Els de Graauw \\ Baruch College, \\ City University of New York \\ Shannon Gleeson \\ University of California, Santa Cruz
}

Irene Bloemraad University of California, Berkeley

\begin{abstract}
The authors argue that taken-for-granted notions of deservingness and legitimacy among local government officials affect funding allocations for organizations serving disadvantaged immigrants, even in politically progressive places. Analysis of Community Development Block Grant data in the San Francisco Bay Area reveals significant inequality in grants making to immigrant organizations across central cities and suburbs. With data from 142 interviews and documentary evidence, the authors elaborate how a history of continuous migration builds norms of inclusion and civic capacity for public-private partnerships. They also identify the phenomenon of "suburban free riding" to explain how and why suburban officials rely on central city resources to serve immigrants, but do not build and fund partnerships with immigrant organizations in their own jurisdictions. The analysis affirms the importance of distinguishing between types of immigrant destinations, but argues that scholars need to do so using a regional lens.
\end{abstract}

\section{INTRODUCTION}

When the U.S. federal government launched the War on Poverty during the 1960s, social policy shifted to a model of public-private partnerships where government funding went to local nonprofit organizations and com-

${ }^{1}$ We are indebted to Karthick Ramakrishnan for advice and assistance; to Catherine Barry, Dani Carrillo, Claude Fischer, Cybelle Fox, Heidy Sarabia, Margaret Weir, mem-

(C) 2013 by The University of Chicago. All rights reserved.

0002-9602/2013/119-0003\$10.00 
munity action agencies to provide services to the disadvantaged, especially African-Americans and the urban poor (Grønbjerg 2001; Marwell 2004; Reckhow and Weir 2012). The ongoing privatization and devolution of public services in the 1970s and 1980s led local nonprofits to become key players in service provision, and government funding became an indispensable resource for civil society organizations (Smith and Lipsky 1993; Salamon 1999; Allard 2009). Today various scholars argue that nonprofits, due to their localized service functions, are uniquely situated to understand and advocate for vulnerable populations (Berry with Arons 2005; de Graauw 2008, 2012; McCarthy 2010; Mosley 2011). Given the prevalence and importance of the public-private partnership model - one that provides critical human services and facilitates civic and political voice-which organizations receive government support and why?

We pose this question within the context of a "new geography" of poverty and immigration in the United States. Although the poverty rate remains high in central cities, suburbs housed a larger number of poor people in 2009, and more than two-thirds of net growth in the poor population from 2000 to 2009 occurred in suburbs (Kneebone 2010, p. 2; Kneebone and Garr 2010). Renewed immigration has also generated demographic transformations: the foreign-born population grew from just $5 \%$ in 1970 to $13 \%$ in 2010 (Gibson and Jung 2006; U.S. Census Bureau 2011). Many of these newcomers moved to "new" gateway cities, suburbs, and rural areas rather than to traditional immigrant gateways. Indeed, the changing geography of poverty and immigration are linked: the foreign-born are, on average, poorer than U.S.-born citizens, and today half of all immigrants living in metropolitan areas reside in suburbs (Singer 2004; Singer, Hardwick, and Brettell 2008). ${ }^{2}$

How do immigrant suburbs and new gateway cities respond to foreignborn disadvantaged groups? Do they promote public-private partnerships with organizations that advocate for and provide human and social services to immigrants? These questions take seriously long-standing calls for

bers of the University of California, Berkeley, Interdisciplinary Immigration Workshop, and the AJS reviewers for helpful feedback; to Nij Tontisirin for GIS support; and to the following organizations for financial support: the Nonprofit Academic Centers Council, the Ford Foundation, PSC-CUNY 41, the Russell Sage Foundation, the Hauser Center for Nonprofit Organizations at Harvard University, and the Wellman Family Faculty Fund and former Institute for the Study of Social Change at the University of California, Berkeley. Authors' names are listed in reverse alphabetical order; they are equal coauthors. Direct correspondence to Shannon Gleeson, Department of Latin American and Latino Studies, Merrill Faculty Services, University of California, Santa Cruz, California 95064. Email: sgleeson@ucsc.edu

${ }^{2}$ Low-wage immigration is only one contributor to growing suburban poverty. Gentrification in city centers, which is pricing out poor residents, also plays a role, as does the movement of employment opportunities outside the urban core. 
more research into how urban and suburban locations shape residents' lives, particularly those of immigrants (Waldinger 1989; Baldassare 1992), and to better understand the interaction between political systems and nonprofit organizations that serve and represent vulnerable groups (Andrews and Edwards 2004; Berry with Arons 2005; de Graauw 2008; Mosley 2011). These questions also change the level of analysis in assessing immigrant integration beyond individual-level outcomes such as educational attainment or English language skills to focus on government responsiveness, specifically the public goods provided to organized entities working for immigrant communities.

The very limited scholarship on this topic tends to explain immigrantoriented public-private partnerships through a rational political exchange model in which local government officials make strategic decisions to fund community organizations to achieve political goals. Local elected officials provide immigrant organizations with resources in exchange for votes within a modern form of machine politics in New York City (Marwell 2004, 2007). Similarly, community organizations receive support in suburban Washington, D.C., because they solve service delivery problems for bureaucrats and politicians (Frasure and Jones-Correa 2010). These accounts elucidate the mechanisms within particular cases, but they provide less purchase on variation among municipalities. Why do the dynamics of strategic political exchange not give rise to public-private partnerships for immigrant services everywhere? Comparative research on municipal responses to immigration suggests that partisan ideologies and electoral politics matter (Ramakrishnan and Lewis 2005; Ramakrishnan and Wong 2010), as do feelings of threat and anti-immigrant sentiment in local populations (Hopkins 2010; Brettell and Nibbs 2011). Not surprisingly, these studies find that migrants who move to a liberal or progressive municipality receive a warmer welcome, with more opportunities for public-private partnerships, than those who face anti-immigrant politicians committed to small government and limited public services.

We concur that partisanship and calculated political decisions matter. We argue, however, that government officials' normative understanding of their community and their taken-for-granted notions of deservingness and legitimacy affect funding in ways less intentional than those posited by the rational political exchange model. Differences in how officials identify socially constructed target populations for public policy produce variation in public-private partnerships across immigrant destinations, even in relatively welcoming regions where existing models would predict similar funding patterns toward immigrant groups.

These orientations toward immigrant groups rest on the legacy and institutional scaffolding of prior immigrant settlement. A tradition of immigration makes it "natural" to include immigrants in public-private partnerships. 
Long-standing immigration also generates an organizational infrastructure that facilitates partnerships, particularly in larger cities with more developed bureaucracies. It produces seasoned partners and a foundation upon which new leaders and groups can emerge. This further legitimates immigrants as natural stakeholders in public service provision. Social constructions of legitimacy and on-the-ground organizational infrastructure are mutually reinforcing; together they provide immigrants in traditional gateway cities with more civic presence and a more supportive environment for public-private partnerships than immigrants in new gateway cities or immigrant suburbs. This is the case even in destinations characterized by progressive politics and a proimmigrant environment, and it occurs despite the fact that rapid demographic growth can provide new gateway cities and immigrant suburbs with expanding fiscal resources.

In elaborating this approach, we underscore the importance of a regional lens, especially the geographical proximity of immigrant suburbs to large central cities. Political jurisdictions matter - community organizations and public funding decisions are located within politically delineated spacesbut they must be understood within the context of metropolitan regions. Metropolitan regions are key to research on economic growth, environmental issues, transportation systems, and advocacy for social equity (Gans 2009; Pastor, Lester, and Scoggins 2009; Weir et al. 2012). They are also, we contend, critical to understanding government responsiveness to immigrant residents. Suburbs' proximity to central cities influences suburban officials' recognition of immigrant residents as a target population and their assessment of immigrants' local needs. We find a disjuncture between officials' image of the suburban bedroom community - fed by traditional perceptions that disadvantaged immigrants live in the ethnic neighborhoods of gateway citiesand the reality of immigrants' contemporary suburban settlement. Officials also presume that immigrants can rely on the resources and services provided in other jurisdictions. We conceptualize this phenomenon as "suburban free riding."

Thus, although suburbs are not devoid of civic capacity (Oliver 2001), and some might engage in the bureaucratic incorporation of immigrants (Jones-Correa 2006, 2008), we emphasize that suburban destinations take limited responsibility for foreign-born residents, particularly when those immigrants are disadvantaged and the suburb is located close to a traditional immigrant gateway city. To a significant degree, both elected and nonelected suburban officials do not internalize the "new geography" of immigrant settlement and poverty. They often view immigrant services as something provided in big cities, not in the suburbs where most immigrants now live.

Our arguments draw from a multiyear study of how four different types of cities - a continuous immigrant gateway city (San Francisco), a 21stcentury immigrant gateway city (San Jose), a large suburban immigrant 
city (Fremont), and a smaller suburban immigrant city (Mountain View) support immigrant organizations. We draw on extensive fieldwork, including in-depth interviews with 142 individuals, a database of registered nonprofit organizations, and government reports of municipal funding allocations, to compare these four cities, all located in the San Francisco Bay region. We examine how local government officials respond to the needs of disadvantaged immigrant residents by assessing the financial resources they allocate through the Community Development Block Grant (CDBG) program, a legacy of the public-private partnership model launched by the War on Poverty.

In what follows, we first describe how public-private partnerships that serve disadvantaged populations have changed over time. We then theorize how place matters in explaining variation in public funding for immigrant services. After outlining our research design and data sources, we document significant inequality in resource allocation across municipalities within the same region. To understand the findings, we elaborate the phenomenon of suburban free riding and discuss how varied historical legacies of immigrant settlement influence civic and bureaucratic infrastructures as well as local officials' constructions of immigrants as target populations of public policy. We conclude by exploring the implications of our findings and considering whether they might hold for other metropolitan regions.

\section{FUNDING HUMAN AND SOCIAL SERVICES ACROSS PLACE AND TIME}

Attention to place is critical for understanding public-private partnerships that target disadvantaged groups: the poor tend to be concentrated in particular areas, community organizations operate in specific locations, and government allocations are usually made within circumscribed political jurisdictions. For example, since 1974, when the CDBG program consolidated seven existing federal assistance programs, officials in disadvantaged areas have received federal monies based on local needs within their jurisdictions. When welfare reform brought on significant cuts to social assistance in 1996- the number of people receiving cash assistance plummeted from 14.2 million in 1994 to 3.8 million in 2008 (Danziger 2010, p. 528) - poor people grew even more reliant on community organizations for services and resources, as well as for social networks and advocacy (de Graauw 2008, 2012; Small 2009; Mosley 2011). The growth of poverty in U.S. suburbs has created a spatial mismatch between traditional service providers located in central cities and the places where more and more poor people live (Puentes and Warren 2006; Allard 2009; Panchok-Berry, Rivas, and Murphy 2011; Reckhow and Weir 2012; Kneebone and Berube 2013).

Immigrants with limited means face multiple disadvantages. Data from the American Community Survey indicate that $14.8 \%$ of native-born Amer- 
icans lived in poverty in 2010, compared to $18.8 \%$ of the foreign-born and a staggering $25.1 \%$ of noncitizen immigrants. ${ }^{3}$ Yet many immigrants are barred from direct cash assistance, and many face barriers accessing public institutions and nonprofit organizations set up for English-speaking nativeborn citizens. Furthermore, the United States, unlike many other Western countries, does not have a federal immigrant integration policy; it has instead an uncoordinated patchwork of programs spread across multiple levels of government that exists within an overall laissez-faire approach to immigrant settlement (Bloemraad and de Graauw 2012). Immigrants must rely on family, coethnic networks, and community organizations for assistance and human services.

Historically, immigrant gateways like New York, Chicago, and Boston housed the majority of immigrants and the organizations that served them. Urban immigrants received social services, a civic education, and political inclusion from ethnic mutual aid societies (Beito 2000), religious institutions (Dolan 1975), labor unions (Sterne 2001), settlement houses (Trolander 1987), and political machines (Dahl 1961). Consonant with ecological models of spatial assimilation (Park 1926; Massey 1985), movement to the suburbs - which correlated with greater English ability, longer U.S. residence, and more socioeconomic resources (Alba et al. 1999; Wright, Ellis, and Parks 2005; Iceland and Nelson 2008) — meant a reduced need for social and human services and diminished interest in immigrant organizations catering to linguistic and cultural differences.

Today the image of the traditional gateway city with its institutionally complete ethnic neighborhoods does not reflect the totality of immigrant settlement. Immigrants now skip traditional gateways and settle directly in new gateway cities and suburbs (Singer 2004; Frey 2006; Jones-Correa 2006). Already in 1980, scholars noted that the historic link between immigration and inner-city neighborhoods was breaking down: two-thirds of non-Hispanic whites in metropolitan areas lived in suburbs, but so too did about half of Koreans, Filipinos, Asian Indians, and Cubans - the vast majority of whom were foreign-born (Alba and Logan 1991). In 2005, $96 \%$ of all foreign-born residents in the United States lived in a metropolitan area and well over half of them resided in suburbs (Singer 2008, pp. 7, 15), giving rise to terms such as "ethnoburbs" and "edge gateways" (Li 1998; Logan, Alba, and Zhang 2002; Price and Singer 2008).

Building on the work of Singer and colleagues (Singer 2004; Singer et al. 2008), we identify three types of communities germane for our study. They are distinguished by their size and historical and contemporary experiences with immigration. First, there are the large central cities that are contin-

\footnotetext{
${ }^{3}$ The proportion refers to those below $100 \%$ of the federal poverty level. Calculations are by the authors from the U.S. Census FactFinder tool.
} 
uous immigrant gateways, such as New York, Chicago, and San Francisco. They have had large immigrant populations for more than a century at proportions far above the national average. In comparison, 21st-century gateways, such as Atlanta, Washington, D.C., and San Jose, have emerged as major immigrant destinations over the last few decades as their immigrant populations tripled or quadrupled in size (Singer 2008, pp. 8-9). A third type, suburban immigrant communities, are like the 21 st-century gateways in that their experience with migration is recent and characterized by dramatic increases in the proportion of immigrants. They differ, however, in their absolute size, with many fewer residents and correspondingly smaller and less complex government bureaucracies. ${ }^{4}$

The new gateway cities and immigrant suburbs are home to large numbers of people who face some of the same linguistic, economic, social, and cultural challenges that made urban organizations so important to European newcomers a century ago. Contemporary immigrant organizations provide social services (Marwell 2004, 2007; Cordero-Guzmán 2005), fight labor law violations (Gleeson 2008; Martin 2012), express identities through cultural and religious activities (Brettell and Reed-Danahay 2012), advocate for public policies (de Graauw 2008, 2012), and promote civic and political incorporation (Bloemraad 2006; Ramakrishnan and Bloemraad 2008; Okamoto and Ebert 2010). The bridging work of community organizations, long a hallmark of immigrant integration, becomes even more critical given welfare state privatization, the absence of a national integration policy, and the elusive goal of federal immigration reform.

Today's landscape of charitable service provision is, however, very different from a century ago. Not only is there an increasing spatial mismatch between traditional service organizations and the new geography of immigration but nonprofit service provision is much more entrenched in publicprivate partnerships. By 1997, after more than two decades of privatization and devolution, just over half of federal, state, and local government funds for social services went to nonprofits (Salamon 2003). A recent survey of large human service nonprofits found that government funding accounts for over $65 \%$ of total revenue and that $60 \%$ of organizations with government funding report that these monies are their largest source of income (Boris et al. 2010, p. vii). Among the limited studies reporting financial data for large immigrant-serving nonprofits, there is a similar reliance on public funding (Bloemraad 2005; Cordero-Guzmán 2005; de Graauw 2008, 2012; Frasure

\footnotetext{
${ }^{4}$ While suburbs can be defined by a population threshold or based on commute time to work, our conception rests on a political delineation of space, which, as Massey and Denton (1988) note, divides metropolitan areas into mutually exclusive units of local government that affect property taxes, education systems, etc. Our designation also reflects suburban officials' distinctions among the Bay Area's big cities and what they see as their qualitatively different bedroom communities, even if they are relatively large.
} 
and Jones-Correa 2010). Given that public-private partnerships have become integral to the American welfare state and advocacy efforts for marginalized groups, do different types of municipalities provide immigrant organizations with equitable shares of public resources? If there are differences between municipalities, what accounts for them?

\section{THEORIZING HOW PLACE MATTERS}

Recent accounts of public-private partnerships with immigrant communities focus on rational political exchange. Elected and nonelected local government officials make strategic decisions to fund immigrant organizations to achieve political goals. Studying social service provision in eight community organizations in New York City, Marwell (2004, 2007) identifies a new form of machine politics. In a process of triadic exchange, elected city officials provide a community organization with patronage resources via government contracts, the community group provides patronage jobs and services to those who support the elected officials, and residents of the community provide votes to incumbents. One implication of this model is that organizations that fail to provide votes might not receive funding. Yet only one of Marwell's eight organizations engaged in machine politics, which suggests that community organizations can access resources by means other than political exchange. This is important because electoral mechanisms are problematic for immigrants: only $44 \%$ of the foreign-born had U.S. citizenship and the right to vote in 2010 .

Frasure and Jones-Correa (2010) extend the political exchange model to include nonelected officials. Studying day labor centers that cater mostly to noncitizen immigrants in new immigrant suburbs ringing Washington, D.C., they underscore the role of local bureaucrats who need to overcome language and cultural barriers in serving immigrant residents but lack the fiscal resources or service abilities to do so. Bureaucrats thus off-load human and social service work to community organizations that act as linguistic and cultural brokers and initiate, deliver, and staff services to immigrant residents. Elected officials go along with such partnerships because they can take credit for the programs with minimal use of municipal resources, possibly building future support among immigrant communities while limiting the political costs that could accompany a significant investment in new immigrant residents. The attention to a diverse set of public officials is important since both elected and nonelected officials influence how CDBG grants are distributed (Rimmerman 1985; Rich 1993; Rosenfeld, Reese, and Georgeau 1995).

Yet exchange models — either through vote buying or exploiting immigrant community resources - leave important questions unanswered, including how to explain variation in public support for immigrant services across different types of municipalities. Why do not all cities fund immigrant organizations, 
given either machine politics or bureaucrats' desire to leverage local civic capacity? Scholarship examining variation among municipalities has largely focused on a converse process, anti-immigrant policy making, which denies immigrant residents access to public and private resources. Ramakrishnan and Wong (2010) find that political factors - especially the partisanship of local residents - matter more than demographic or economic factors in explaining why some municipalities propose and pass anti-immigrant ordinances. Hopkins (2010) contends that when national anti-immigrant rhetoric is politicized into feelings of threat at the local level, demographic change increases the probability of anti-immigrant ordinances. Both arguments focus on a political exchange in which elected officials propose anti-immigrant policies to garner votes from (largely native-born) partisan supporters.

We find it highly plausible that public-private partnerships for immigrant human services are more prevalent in municipalities where immigrants constitute a substantial proportion of the voting population and where voters are more politically progressive and favorably disposed toward immigrants. These elements characterize most of the cities and suburbs ringing the San Francisco Bay, including the four we studied. Yet, as we document below, there is significant variation among Bay Area localities in their support for immigrant organizations and in their views of disadvantaged immigrants. Our research elaborates alternative mechanisms that influence resource distribution, ones that go beyond strategic political exchange and partisanship.

We instead focus on the dynamics that lead public officials to identify immigrants as legitimate targets of public policy and as partners with local government. We draw on Schneider and Ingram's (1993) theory of the social construction of target populations in public policy. Such constructions employ explicit and implicit normative characterizations of a particular group that communicate who is deserving of public attention, what government should do for the group, and the appropriate participatory patterns for the group (Schneider and Ingram 1993, p. 334). Attention to officials' rationales and assumptions helps explain why some groups are advantaged over others independent of traditional measures of political power or seemingly objective evaluations of need (Schneider and Sidney 2009, p. 105). ${ }^{5}$ This approach seems particularly fruitful for studying immigrants who, in political discourse, are simultaneously demonized as law breakers, welfare abusers, job stealers, and national security threats (Santa Ana 2002; Martinez and Valenzuela 2006; Chavez 2008; Newton 2008) and valorized as hard workers, future citizens, and freedom fighters (Voss and Bloemraad 2011). We do not focus on one particular group of immigrants but rather on the

\footnotetext{
${ }^{5}$ Schneider and colleagues are particularly interested in policy design and content. We are primarily interested in how policy is applied given changing demographics, which they highlight as an important area for research.
} 
general designation of immigrants as a constituency with needs that can be served by public-private partnerships through programs like CDBG.

We also draw on Ramakrishnan and Bloemraad's (2008, p. 20) idea of immigrants' civic presence to examine how organizational infrastructures feed into social constructions of legitimacy. These infrastructures include bureaucracies set up by local governments to deal with particular groups as well as immigrant communities' civic organizations. In focusing on immigrant organizations, we underscore the symbolic and instrumental importance of formalized organizations doing routinized service work-what Walker and McCarthy (2010, p. 318) term an organization's sociopolitical legitimacy — as distinct from a political mobilization perspective that highlights the protest tactics employed by social movement organizations. ${ }^{6}$ When it comes to public-private partnerships, robust organizational infrastructures facilitate immigrants' ability to establish a track record of service and advocacy that elected and nonelected city officials draw upon in defining target populations and accounting for funding allocations (de Graauw 2008, 2012; Ramakrishnan and Bloemraad 2008). Together legitimacy and organizational infrastructures produce differences in civic presence that help generate hypotheses about how different types of localities react to needy immigrant residents.

\section{Continuous Immigrant Gateways and the Legacies of History}

We posit that a sustained experience with migration in traditional gateway cities facilitates the creation and reenforcement of norms that immigrants are legitimate target populations of policy and public-private partnerships. This does not mean that immigrants are uniformly welcomed-indeed, residents can challenge whether public resources should go to them-but it does mean that immigrants are an established part of city services and decision making. A city's long history of migration provides discursive structures and established claims-making frames upon which new groups can make appeals even if "new" immigrants are not welcomed as readily as "older" groups. The legacy of continuous migration also builds up an infra-

\footnotetext{
${ }^{6}$ While some of the organizations in our research can be considered "hybrid organizations," i.e., groups that fulfill multiple roles such as service, organizing, and advocacy, for the most part groups that receive CDBG funds are not typical social movement organizations. This is a conclusion also reached by others who study human and social service organizations (e.g., Mosley 2011). Few of the organizations we study foster "direct participation of their constituents," which may be considered the hallmark of social movement organizations, nor do they for the most part engage in protest or other types of "extra-organizational collective action" (Minkoff 1997, pp. 786, 780). Such activities and goals better characterize other groups in the immigrant rights movement that work directly for the legalization of undocumented residents (Voss and Bloemraad 2011).
} 
structure of city institutions and immigrant organizations experienced in addressing immigrants' needs and interests.

In contrast, immigrants in 21 st-century gateways and suburbs - both places of new immigrant settlement - must establish organizational infrastructures and gain legitimacy in the eyes of elected and nonelected city officials. All things equal, this transition is likely easier in big 21st-century gateways. A central city's greater size generates a larger, more professional city bureaucracy, with greater capacity to develop relationships with community organizations and a larger funding pot that city officials can allocate to more groups, including immigrant organizations (Ramakrishnan and Lewis 2005; de Graauw 2012). Larger cities are also more likely to hold social constructions of their community that include disadvantaged residents. Thus, we posit that 21 st-century gateways will move more quickly to extend public-private partnerships to immigrants than suburbs, even though both are new to dealing with significant foreign-born populations.

\section{Regional Dynamics and Suburban Free Riding}

Suburbs have long been considered the bastion of middle-class white residents who seek to escape urban social problems and redistributive tax systems (Baldassare 1992; Gainsborough 2001; Oliver 2001; Jones-Correa 2006). A traditional way of viewing suburban-central city relations is through the concept of parasitic or exploitative suburbs. Suburban residents free ride on the services, cultural vitality, and economic opportunities of the racially and socioeconomically diverse central city, but they do not pay fully for those benefits since their property taxes go to maintenance services and suburban school systems rather than redistribution and social services benefiting the poor (Kasarda 1972; Hill 1974; Oliver 2001).

We speculate that an analogous process of suburban free riding occurs with immigrant services. That is, suburban immigrants are expected toand at times do - seek out human and social services offered by immigrant organizations in central cities, even if they do not live there and do not contribute property taxes to the central city. However, these suburban residents are not engaged in a conscious calculation of taxation costs and central city benefits when they turn to central city organizations; they turn to these services because the free riding of suburban officials leaves them with no comparable suburban option. Our use of the term "free riding" is thus meant to evoke the idea that suburban officials rely on a public good provided by and paid for by others to meet their residents' needs without incurring costs themselves. $^{7}$ This can be the product of an official's rational calculation of

${ }^{7}$ Collective action or game-theoretic models of free riding center on a self-interested individual's presumed rational decision to not contribute to a public good or other col- 
fiscal costs versus electoral benefits, but it need not be. Instead, in line with our approach underscoring the social construction of target populations, suburban officials simply have a hard time conceiving of their communities as destinations for disadvantaged immigrants, even if demographic data make that clear and even if they hold progressive ideologies. As a result, immigrants are not recognized as possible targets of grants making nor do suburban officials cultivate immigrant organizations as possible service partners. Indeed, suburban immigrants might face problems precisely because of their proximity to traditional gateways long associated with immigration. Proximity makes free riding easier for suburban officials due to the availability of services elsewhere and because of the iconic image that many hold of the traditional gateway city as the natural place immigrants should go for services and where immigrants are presumed to feel more comfortable seeking assistance.

Thus, unlike the older literature on parasitic suburbs, which pits residents of different metropolitan jurisdictions against each other, the phenomenon of suburban free riding that we identify places the needs of some suburban residents, often long-standing native-born citizens, over those of other suburbanites, in this case disadvantaged immigrants. The privileging of nonimmigrant residents might be done consciously due to anti-immigrant animus or conservative political ideology or for electoral gain, as outlined by prior scholarship. But as we demonstrate, free riding can also occur in politically progressive or moderate suburbs, where immigrant groups are simply not identified as a significant part of the civic landscape.

The attraction of free riding also rests on the reality of limited public funds and the many demands for services faced by public officials. Suburbs have smaller budgets and staffs than their big city neighbors. The sheer number of immigrants in central cities can generate economies of scale, allowing immigrant organizations to better advocate for and offer services to immigrant residents (Marwell 2004, 2007; de Graauw 2008, 2012). Yet the potential fiscal benefits of large size should not be overstated. Central cities often confront substantial budget deficits, and the number of demands made on their complex bureaucracies can be a liability, especially since immi-

lective endeavor because his or her contribution is negligible for the good's provision or for the collective outcome. Yet, since the public good is nondivisible and nonexcludable, he or she will still benefit, thereby "free riding" on the contributions or work of others. A conundrum arises when all individuals make the decision to free riding since in that case the good fails to materialize, a suboptimum outcome for everyone (Olson 1965; Marwell and Ames 1979). Here we employ the term in a slightly different sense. Formal free riding theories focus on individuals, usually in large groups, while we focus on relations among a small number of cities in close proximity and the officials who govern these cities. We nevertheless find the term "free riding" to be useful in this context to the extent that funding provided by large, neighboring cities subsidizes immigrant service provision to suburban residents without any cost to suburban cities' coffers. 
grants can be singled out for funding cuts during periods of severe budgetary strain (Katz 1990). Also, rapid population growth due to immigration can provide expanding fiscal resources for suburbs compared to traditional gateways that have stable or shrinking populations; this in fact occurred with rising CDBG allocations to the immigrant suburbs we study, whereas San Francisco confronted stagnant funding.

\section{A REGIONAL RESEARCH DESIGN: CENTRAL CITIES AND SUBURBS IN THE BAY AREA}

We engage in two comparisons, one contrasting the central cities of San Francisco and San Jose to the suburban cities of Fremont and Mountain View and a second comparing San Francisco, a continuous immigrant gateway, to San Jose, a 21st-century gateway city. Table 1 provides a demographic overview of the four cities, while figure 1 provides a visual representation. ${ }^{8}$ Our approach resembles other comparative studies that include new immigrant destinations (Singer et al. 2008; Andersen 2010; Okamoto and Ebert 2010; Marrow 2011), but an important novelty is that our cities lie in the same region of the Bay Area in northern California. This allows us to uncover how history, city size, and regional proximity matter for legitimacy, organizational infrastructure, civic presence, and public-private partnerships, while controlling for the proportion of immigrants, the ideological bent of public officials, and the regional economy. ${ }^{9}$ Political ideology, in particular, might complicate comparisons, since public-private partnerships are likely more extensive where local officials hold a progressive ideology (Ramakrishnan and Lewis 2005; de Graauw 2008, 2012). ${ }^{10}$

\footnotetext{
${ }^{8}$ Population statistics in table 1 and attributed in the text to 2006 are from three-year averages (2005-7) of the American Community Survey (U.S. Census Bureau 2009). These data match the time period of our CDBG data and field research. The map in fig. 1 is based on 2005-9 ACS data since tract-level data are only available in five-year estimates.

${ }^{9}$ A city's history of refugee resettlement might also matter (Bloemraad 2006; Singer et al. 2008; Andersen 2010), but this often overlaps with a history of migration.

${ }^{10}$ Scholars of urban politics often contrast the political systems of large cities to reformstyle suburban governments, which frequently include a council-manager form of government, at-large representative districts, and nonpartisan elections. The cities of Fremont and Mountain View are not, however, "pure" reform cities: Fremont has an elected mayor and appointed city manager; in Mountain View the mayor and city manager are appointed. San Francisco and San Jose have elected mayors, but they also have reformstyle elements: San Jose has an appointed city manager and San Francisco an appointed city administrator. Local elections, as required by California law, are nonpartisan in all four cities. San Francisco has experimented with both at-large and district elections, reinstituting district elections in 2000. San Jose has had district elections since 1978. Fremont and Mountain View both have city councils elected at-large. There is no stark difference in the cities' political systems.
} 
American Journal of Sociology

TABLE 1

Sociodemographic Profile of Selected Bay Area Cities, 2005-7

\begin{tabular}{|c|c|c|c|c|c|c|c|c|}
\hline & \multicolumn{2}{|c|}{$\begin{array}{c}\text { SAN } \\
\text { FRANCISCO } \\
\end{array}$} & \multicolumn{2}{|c|}{ SAN Jose } & \multicolumn{2}{|c|}{ FrEMONT } & \multicolumn{2}{|c|}{$\begin{array}{c}\text { Mountain } \\
\text { View }\end{array}$} \\
\hline & No. & $\%$ & No. & $\%$ & No. & $\%$ & No. & $\%$ \\
\hline Total population & 757,604 & & 898,901 & & 208,455 & & 71,153 & \\
\hline Non-Hispanic white (only) . . & 338,466 & 45 & 285,249 & 32 & 65,566 & 32 & 33,973 & 48 \\
\hline Non-Hispanic black (only) . . . & 50,750 & 7 & 27,761 & 3 & 6,012 & 3 & 1,052 & 2 \\
\hline Non-Hispanic Asian (only) . . . & 238,344 & 32 & 274,338 & 31 & 96,044 & 46 & 17,959 & 25 \\
\hline $\begin{array}{l}\text { Hispanic or Latino (of any } \\
\text { race) } \ldots \ldots \ldots \ldots \ldots \ldots \ldots\end{array}$ & 105,790 & 14 & 281,651 & 31 & 32,108 & 15 & 15,136 & 21 \\
\hline Foreign-born (of total & & & & & & & & \\
\hline $\begin{array}{l}\text { population }) \ldots \ldots \ldots \ldots \ldots \\
\text { Naturalized U.S. citizen }\end{array}$ & 270,481 & 36 & 350,809 & 39 & 90,522 & 43 & 28,431 & 40 \\
\hline $\begin{array}{l}\text { (of FB pop) } \ldots \ldots \ldots \ldots \ldots \\
\text { Recent migrant, entered US } \\
\text { in } 2000 \text { or later (of FB }\end{array}$ & 166,504 & 62 & 177,498 & 51 & 47,683 & 53 & 9,981 & 35 \\
\hline $\begin{array}{l}\text { pop) } \ldots \ldots \ldots \ldots \ldots \ldots \\
\text { Speaks English less than }\end{array}$ & 50,074 & 19 & 74,054 & 21 & 18,360 & 20 & 8,610 & 30 \\
\hline $\begin{array}{l}\text { "very well" (of FB pop } \\
\text { ages } 5+\text { ) } \ldots \ldots \ldots \ldots \ldots \ldots\end{array}$ & 172,782 & 24 & 222,585 & 27 & 43,978 & 23 & 14,415 & 22 \\
\hline $\begin{array}{l}\text { World region of birth (of foreign } \\
\text { born): }\end{array}$ & & & & & & & & \\
\hline Asia....... & 167,475 & 62 & 201,686 & 58 & 69,135 & 76 & 12,741 & 45 \\
\hline Latin America . . . . . . . . & 56,319 & 21 & 117,879 & 34 & 13,374 & 15 & 9,381 & 33 \\
\hline Europe ............... & 36,804 & 14 & 21,223 & 6 & 4,080 & 5 & 4,959 & 17 \\
\hline $\begin{array}{l}\text { City residents in poverty* ...... } \\
\text { Foreign-born residents in }\end{array}$ & 88,426 & & 90,996 & & 10,969 & & 4,499 & \\
\hline poverty (of all in poverty) ... & 34,400 & 39 & 38,376 & 42 & 5,250 & 48 & 2,383 & 53 \\
\hline $\begin{array}{l}\text { Children under } 18 \text { living in } \\
\text { poverty } \dagger \ldots \ldots \ldots \ldots \ldots \ldots\end{array}$ & 30,628 & & 63,312 & & 8,094 & & 3,528 & \\
\hline $\begin{array}{l}\text { Children in poverty with } \\
\text { one or more foreign-born }\end{array}$ & & & & & & & & \\
\hline 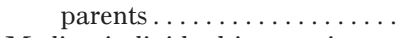 & 22,228 & 73 & 45,020 & 71 & 5,789 & 72 & 2,865 & 81 \\
\hline $\begin{array}{l}\text { Median individual income in } \\
\text { past } 12 \text { months }(\$) \text { : }\end{array}$ & & & & & & & & \\
\hline All residents $\ldots \ldots \ldots \ldots \ldots$ & 33,984 & & 32,277 & & 40,541 & & 45,038 & \\
\hline Foreign-born residents . . . . . . & 22,721 & & 29,948 & & 43,573 & & 37,228 & \\
\hline
\end{tabular}

Note.-American Community Survey, three-year estimates, 2005-7 (U.S. Census Bureau 2009).

* Individuals living below $100 \%$ of the federal poverty level, past 12 months.

$\dagger$ Children under age 18 living at 200\% or less of federal poverty level, past 12 months.

San Francisco is a densely populated central city with 757,604 residents concentrated on 49 square miles of land. San Jose is a sprawling city of 898,901 residents across 174 square miles. Fremont is a large suburban city, with a population of 208,455, located east of the San Francisco Bay. Mountain View is a smaller suburban city of 71,153 between San Francisco and San Jose. Both suburbs are relatively well off but have pockets of significant poverty - they are what Panchok-Berry, Rivas, and Murphy (2011) have 


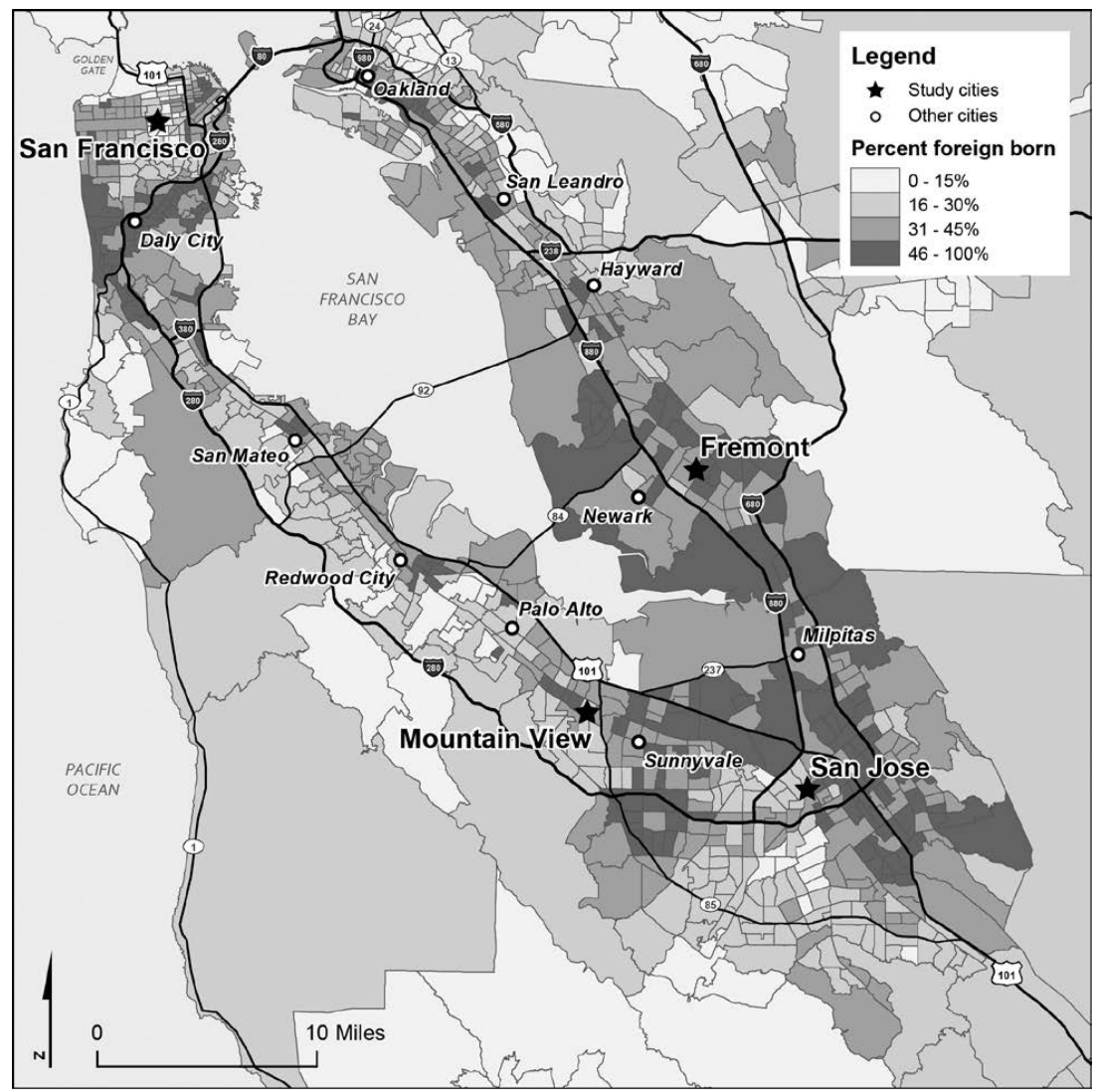

Fig. 1.-Proportion of foreign-born residents, San Francisco Bay Area, ca. 2007. Prepared by Nij Tontisirin with data from 2005-9 American Community Survey (tractlevel estimates), U.S. Census Bureau.

labeled "overshadowed suburbs."11 All four cities are Democratic strongholds; voters overwhelmingly voted for Democratic candidates in the past two presidential elections. All four cities have at least one local elected official who belongs to an ethnoracial minority group other than African-American. They also all have hourglass economies with job growth concentrated at the top (high-paying professional and managerial jobs) and the bottom (lowpaying services jobs). More than a third of each city's population is foreignborn, ranging from $36 \%$ in San Francisco to $43 \%$ in Fremont. As figure 1 makes clear, almost all census tracts in the region house a far higher per-

${ }^{11}$ Our study design does not permit further distinctions among suburbs by overall poverty level or change in poverty (Allard 2009) or by the particular political, social, and institutional differences in suburban poverty (Panchok-Berry, Rivas, and Murphy 2011). Studying intersuburban variation is an important next step in this field. 
centage of foreign-born residents than the national average in 2006 (12.5\%), and in many the proportion is three or four times greater. More than a fifth of each city's residents speak English "less than very well." Compared to their incidence in the general population, immigrants make up a larger share of the poor in all four cities, and the children of immigrants - those with at least one foreign-born parent - constitute a dramatically higher proportion of young people living in disadvantaged households than children with two nativeborn parents. Whether in suburbs or central cities, immigrants face socioeconomic and immigrant-specific needs due to poverty, linguistic isolation, and, in some cases, precarious legal status.

\section{Continuous Gateway City: San Francisco}

Immigration research has long centered on historic gateways such as New York and Los Angeles, yet San Francisco is a prime example of a continuous gateway city. Incorporated in 1850, by 1920 San Francisco had a population of 507,000, $29 \%$ of whom were foreign-born. This proportion was nearly twice the national average of $13 \%$. When the foreign-born population dipped below $5 \%$ nationally in the 1960 s and 1970 s, immigrants still made up $19.3 \%$ of San Francisco's population in 1960 and $21.6 \%$ in 1970. By 2006, $36 \%$ of city residents were born abroad, compared to $12.5 \%$ nationwide. The largest proportion, $62 \%$, hail from Asia, while $21 \%$ and $14 \%$, respectively, are from Latin America and Europe. Almost a fifth are recent migrants who moved to the United States in the prior six years. Immigrants in San Francisco are somewhat more likely to be naturalized citizens - 62\% - and despite the very high cost of living, they make up a somewhat smaller proportion of individuals living in poverty, at $39 \%$, than in the other three cities. However, as in the other cities, the proportion of foreign-born among the city's poor population is greater than the percentage of immigrants in the general population. Moreover, children living with at least one immigrant parent constitute an astounding $73 \%$ of all young people living in disadvantaged households. ${ }^{12}$

San Francisco embraces a narrative as a city of immigration, not the least because famous neighborhoods like Chinatown, the Mission, Japantown, and North Beach are important tourist destinations. The city has adopted legislation of symbolic value to immigrant communities, including naming newer ethnic neighborhoods, like "Little Saigon," and it has passed legislation of substantive importance, such as declaring itself a "sanctuary"

\footnotetext{
${ }^{12}$ Poverty statistics are for individuals living under $100 \%$ of the federal poverty threshold, a metric based on an adequate food plan for different-sized families, without adjustment for local cost of living. The data on children in disadvantaged households are for those living under 200\% of this threshold. Given the Bay Area's high cost of living, people in this situation are in extremely disadvantaged conditions.
} 
for undocumented immigrants in 1986 and adopting language access legislation in 2001 (de Graauw 2008, 2012). Unlike the other three cities, San Francisco has two municipal agencies with specific immigrant-related mandates: the Immigrant Rights Commission, established by ordinance in 1997, and the Office of Civic Engagement and Immigrant Affairs, which in 2009 consolidated a handful of city administrative positions and offices responsible for immigrant integration programs. In fiscal year 2005-6, San Francisco's operating budget was $\$ 5.3$ billion. Despite its immigrant legacy, in 2006, only one of 11 city legislators was Chinese American and one was Latino. ${ }^{13}$

\section{Twenty-First-Century Gateway City: San Jose}

San Jose was also incorporated in 1850 , but it is a 21 st-century immigrant gateway. In 1920, San Jose was a small regional center, with fewer than 40,000 residents. Although roughly $21 \%$ were foreign-born in 1920, migration was not sustained. By the 1960s, the proportion of immigrants had declined to just $8 \%$ (Gibson and Jung 2006). A turning point came when San Jose's economy, previously centered on farming, food processing, and distribution, transformed to become the high-tech capital of Silicon Valley. In 2006, San Jose was the region's largest city, with a population of almost 900,000 . Immigration fueled part of its dramatic growth: by $2006,39 \%$ of San Jose residents were immigrants, with 58\% from Asia and 34\% from Latin America. As in San Francisco, about a fifth are recent migrants. Despite images of Silicon Valley wealth, over 90,000 city residents live in poverty. Of these individuals, $42 \%$ are foreign-born, a proportion greater than in San Francisco and greater than immigrants' share of the general population. Seventy-one percent of children in disadvantaged households have at least one immigrant parent.

San Jose officials usually promote proimmigrant positions, as when city council unanimously reaffirmed the police department's policy not to arrest persons merely due to unauthorized status (San Jose City Council 2007). The bureaucratic infrastructure directed at immigrants is, however, less developed than in San Francisco, reflecting the city's 21st-century gateway designation. San Jose's Strong Neighborhood Initiative, established in 2002, works with many immigrant organizations to foster civic engagement (City of San Jose 2009), but no city agency is specifically dedicated to immigrant affairs. In fiscal year 2005-6, San Jose's operating budget was $\$ 2.7$ billion. In 2006, two of the 10 city councilors were Latino, as was Mayor Ron Gonzales, and one councilor was Vietnamese American.

\footnotetext{
${ }^{13}$ A third local legislator was African-American; non-Hispanic whites held almost threequarters of legislative seats.
} 
American Journal of Sociology

\section{Large Suburban City: Fremont}

Fremont lies east of San Jose, at one end of the region's major transit line. Incorporated in 1956 when five small communities amalgamated, its population stood at 44,000 in 1960, only $5 \%$ of which was foreign-born (ABAG 2011). When Portuguese immigrants came to the city as dairy farmers in the 1960s, they were greeted by orchards. In the 1990s, the city went hightech, attracting high-skilled migrants. Fremont experienced significant economic and population growth, though not on the scale of neighboring San Jose. It is the largest suburb in the region, but Fremont has a similar feel to other Bay Area suburbs. In interviews, several city officials emphasized that Fremont is largely a bedroom community, one that is qualitatively different from the central cities ringing the Bay.

By 2006, Fremont was home to 208,000 residents, $43 \%$ of whom were born abroad. Fremont has the highest proportion of Asian migrants (76\%) of the four cities, while $15 \%$ have origins in Latin America. As in San Jose and San Francisco, about a fifth of Fremont's immigrants are recent arrivals, and just over half (53\%) are naturalized citizens. Fremont's foreignborn have the highest median incomes of all four cities, and the incidence of poverty is relatively low. Nevertheless, of those who are poor, almost half (48\%) are immigrants. Among children in disadvantaged households, $72 \%$ have at least one immigrant parent. Thus, while the proportion and number of people living in poverty is lower than in the neighboring central cities, among Fremont's poor, immigrants are hit hard. They constitute a greater proportion of the poor population than their share of the general population and a higher proportion of poor residents than in San Francisco or San Jose.

Fremont resembles San Jose in its symbolic support for immigrants but limited infrastructure for dealing with immigrant integration. Fremont lacks an agency dedicated to immigrant affairs, and its Office of Neighborhoods - which worked to promote civic engagement among low-wage and immigrant communities - was defunded in 2005 under budget pressures. In fiscal year 2005-6, Fremont's operating budget was \$233 million. Two city councilors were Asian American in 2006, one with origins in India and one of Chinese background.

\section{Small Suburban City: Mountain View}

Mountain View, also situated on a major regional transit line, lies between San Francisco and San Jose, across the Bay from Fremont. The city was incorporated in 1902 with barely 600 residents. By midcentury, the population stood at 6,548, with only $9 \%$ born outside the United States (ABAG 2011). As in San Jose and Fremont, the second half of the 20th century brought demographic growth and economic transformation. The city is home to sev- 
eral high-tech giants and a former naval facility now serving as a NASA research site. Population growth has been more muted - in 2006, the population was just over 71,000 residents-but immigration is as significant. In 2006, $40 \%$ of Mountain View residents were foreign-born: $45 \%$ from Asia, $33 \%$ from Latin America, and 17\% from Europe. Slightly more migrants are recent - 30\% had entered the country since 2000 — and fewer are naturalized citizens $(35 \%)$. The proportion of immigrants among residents living in poverty is the highest among the four cities, at $53 \%$, as is the proportion of children living in disadvantaged families with at least one immigrant parent, $81 \%$. Mountain View is thus a suburb with a significant immigrant presence, many of whom have urgent human and social services needs.

Mountain View also lacks a municipal office dedicated to immigrant affairs, relying instead on the leadership of its sole Latina councilwoman and the work of the Human Relations Commission. Analogous to some of the Washington, D.C., suburbs studied by Frasure and Jones-Correa (2010), Mountain View has allowed the establishment of a day labor center, one of only a few in the South Bay. Beyond facilitating employment, the center mobilized the Latino community for a large immigrant rights march in 2006 (Tanenbaum 2006). In fiscal year 2005-6, Mountain View's operating budget was $\$ 193$ million.

\section{DATA AND METHODS}

We rely on four data sources: (1) funding data on each city's allocation of CDBG funds to community organizations; (2) a database of 6,828 formally registered nonprofit organizations in the four cities; (3) 142 in-depth interviews with elected and appointed city officials, leaders of community organizations, and immigrant advocates; and (4) documentary information from local governments, immigrant organizations, and local ethnic and mainstream media.

\section{Community Development Block Grants}

Our primary outcome indicator is allocations from CDBG funds over three fiscal years, 2004-5, 2005-6, and 2006-7, as reported in the Consolidated Annual Performance and Evaluation Reports for each city we studied. ${ }^{14}$ The

\footnotetext{
${ }^{14}$ San Francisco is a city-county consolidation, whereas San Jose, Fremont, and Mountain View are cities located in two different counties that include many other municipalities. Our study includes CDBG allocations only for these four cities, but not CDBG allocations for Santa Clara County (which includes San Jose and Mountain View) or Alameda County (which includes Fremont). Santa Clara and Alameda are very large counties with dozens of municipalities that compete for county $\mathrm{CDBG}$ funds; inclusion
} 
CDBG program dates from 1974 and is one of the longest-running programs of the U.S. Department of Housing and Urban Development (HUD). HUD distributes grants across the country, using a standard formula. CDBG funds must be spent on community development, including direct services to lowand moderate-income persons, affordable housing, and infrastructure improvements; recipient governments must document that a majority of funding targets low- and moderate-income areas (Handley and Howell-Moroney 2010). Within these rules, local officials have substantial discretion over CDBG allocations, with most funds dispersed among community organizations. Federal funds are thus allocated to governments via a formula that is exogenous to local political dynamics, yet localities have significant control over grants making (Rich 1993; Rosenfeld et al. 1995). This makes CDBG allocations a unique measure permitting comparison of municipal responsiveness to disadvantaged immigrant populations among old and new immigrant destinations, as well as big cities and small suburbs.

CDBG grants to community organizations are allocated through an open and competitive process. In the cities we studied, once applications are received, city commissions review them, formulate funding recommendations, and invite public feedback. City legislators review the recommendations, convene more public hearings where applicants can testify, and then vote to finalize allocations. ${ }^{15}$ If successful, community organizations must spend CDBG monies on programming in the city where they receive funding.

of CDBG county funding would have added an extra layer of methodological and analytical complication. Despite this jurisdictional mismatch, CDBG grant allocations are comparable across the four cities in large part because HUD rules require that county funds only go to community organizations serving populations in counties' unincorporated areas. Because nonprofits serve a wide range of clients, recipients of county CDBG grants often also receive city CDBG grants. Our examination of the CDBG grantee lists over 2004-7 for Santa Clara and Alameda Counties show that organizations receiving county funds often received city funds as well. CDBG monies awarded to cities are a more reliable metric to compare local responsiveness to immigrant communities. Other local sources of discretionary funding, such as social service contracts, are managed by counties, making it impossible to isolate contracts for a particular city.

${ }^{15}$ There is one CDBG funding cycle per year, and the allocation process is similar across cities. Cities typically issue requests for proposals in November, with applications due in January of the following year. For the cities we studied, the commissions that review CDBG proposals are the Citizen's Committee on Community Development (San Francisco), the Neighborhood Services and Education Committee (San Jose), the Senior Citizens and Human Relations Commissions (Fremont), and the Human Relations Commission (Mountain View). City legislators finalize allocations by April or May. Nonelected staff administer the CDBG funds. These are the Mayor's Office of Community Development (now the Community Development Division within the Mayor's Office of Housing) in San Francisco, the Department of Housing in San Jose, the Human Services Department in Fremont, and the Community Development Department in Mountain View. CDBG funds are made available to grantee organizations for the fiscal year starting July 1 . 
While elected officials ultimately determine CDBG allocations, city administrators and nonelected officials can play important roles in grants making, from encouraging organizations to apply and providing application assistance to making funding recommendations. In the spirit of the original public-private partnership model of the 1960s, HUD also requires cities to engage in public outreach throughout the grants-making process, from establishing the guidelines used to allocate money to convening public hearings before and after allocation decisions. ${ }^{16}$ Municipal differences in the degree of outreach, and whether this includes immigrant communities, can carry significant implications for which groups apply and eventually receive funding.

CDBG funds are significant for both cities and community organizations. The CDBG program is the largest source of discretionary federal aid awarded to local governments, and the amount of money involved is substantial (Brooks, Phillips, and Sinitsyn 2011). In 2006, during our fieldwork, the federal government allocated $\$ 3.7$ billion to formula grants (Boyd 2011, p. 13). Among localities receiving grants, CDBG monies constituted $1.6 \%$ of total spending (Brooks and Phillips 2008, p. 253). Contrary to the expectations of some economists who predicted that cities would reduce taxes by the same amount as the federal grants received, cities that received CDBG funds increased total expenditures by $\$ 0.77$ on every dollar of grant money (Brooks and Phillips 2008, p. 246). This represents real resources for disadvantaged groups.

For community organizations, the award of a CDBG grant can have important spillover effects. Winning one type of grant often facilitates further fundraising and increases the probability of future resources (PanchokBerry, Rivas, and Murphy 2011). Large service nonprofits hold an average of six government grants and contracts per organization, with a median of three distinct grants or contracts (Boris et al. 2010). Receiving public funds can breed a virtuous revenue circle for organizations and also appears to increase nonprofits' ability to advocate for vulnerable populations (Bloemraad 2006; Child and Grønbjerg 2007; Mosley 2011). Other researchers have used CDBG allocations to measure local public policy responsiveness and resource allocation to racial minority populations (Browning, Marshall, and Tabb 1984; Hero 1990; Rich 1993). CDBG allocations thus provide some indication of broader patterns of government support or exclusion.

We believe that our use of CDBG grants as an indicator of local responsiveness can be usefully extended to other localities. CDBG funds are

${ }^{16} \mathrm{HUD}$ requires cities to develop five-year consolidated plans to identify the community development goals against which CDBG applications are evaluated, and it requires community involvement in drafting the plans. HUD also mandates a citizen participation plan to document efforts at public engagement (Rimmerman 1985; Handley and HowellMoroney 2010). 
available to large and small cities - our four cities have received them for over 30 years - and grants may go to different types of community organizations, including those serving immigrants. On many fronts, central cities and suburbs are hard to compare, but the terms of CDBG funding allow for a useful comparative metric. This metric also provides an innovative way to examine immigrant integration dynamics beyond standard individuallevel indicators such as educational attainment, language ability, and voting. CDBG funding gets at group-level recognition and collective goods. We compare the proportion of CDBG funding received by immigrant organizations to the share of immigrants in the city's population.

\section{Nonprofit Organizations and Civic Capacity}

It is difficult, however, for localities to support immigrant organizations if few organizations exist and immigrant civic capacity is low. To receive CDBG funding, organizations must be registered as 501(c)(3) nonprofit organizations. We thus take immigrant civil society into account using a National Center for Charitable Statistics (NCCS) database of all 501(c)(3) nonprofits registered with the Internal Revenue Service (IRS). ${ }^{17}$ Based on the address provided to the IRS, we identified 6,828 organizations with 501(c)(3) status across the four cities. We coded each organization as primarily an immigrant organization or not. We define immigrant organizations as nonprofits whose mission is to serve or advocate on behalf of one or more immigrant communities, promote their cultural heritage, or engage in transnational relations with countries of origin. We base the designation of immigrant organization on cues in the organization's name, information in the group's mission statement, in-depth interviews, media statements, web descriptions, and other documentary sources, including local directories of human service agencies. ${ }^{18}$ In total, we counted 1,151 immigrant organizations, $17 \%$ of all registered nonprofits, which is a much smaller share than immigrants' $38 \%$ of the population in the four cities. This figure corroborates other studies documenting immigrants' underrepresentation in the nonprofit sector (Cortés 1998; Hung 2007; Ramakrishnan and Bloemraad 2008; Gleeson and Bloemraad 2012).

We focus on immigrant organizations because mainstream organizations often have inadequate language services or do not provide assistance

\footnotetext{
${ }^{17}$ We excluded private foundations with 501(c)(3) status; they are often private tax shelters and are treated as distinct entities in analyses by nonprofit scholars (e.g., Boris and Steuerle 2006).

${ }^{18}$ Other studies of immigrant or minority nonprofits use different identification criteria, including the origins of directors and board members (Hung 2007; De Vita, Roeger, and Niedzwiecki 2009) or client characteristics (Cordero-Guzmán 2005; de Graauw 2008, 2012; Martin 2012). We focus on overall mission and activities using a wide array of sources. For details on methodology, see Gleeson and Bloemraad (2012).
} 
germane to immigrants, such as translation services, culturally appropriate human services, or immigrant-related legal services. As others have argued, and our research shows, immigrant organizations are overwhelmingly community-based and specialize in serving low-income, limited-English residents (Cordero-Guzman 2005; de Graauw 2008, 2012; Martin 2012). Many also build immigrants' civic skills and leadership potential and advocate for them to policy makers (Bloemraad 2006; de Graauw 2008, 2012; Gleeson 2008), activities in line with the community empowerment models that animated early public-private partnerships under the War on Poverty. ${ }^{19}$

Interviews and Archival Evidence

To put funding allocations in context, we examined hundreds of pages of city and federal documents to trace the CDBG allocation process and better understand interactions between immigrant organizations and city officials. These sources included materials such as the CDBG consolidated plans of each city and reports of public hearings. Strikingly, while the CDBG program has been around for decades, and all our cities have long histories of receiving funds, formal reporting on the grants-making process is limited, and it is far from transparent. None of the cities we studied disclosed information on the organizations that applied but failed to receive funding, despite our numerous inquiries to a broad range of individuals. We were consequently forced to rely on lists of successful grantees from public documents and requests for information.

We also conducted 142 in-depth interviews between 2004 and 2008. These interviews probed local officials' sense of responsibility to various constituencies, including immigrants, and immigrant organizations' view of their relationship with city government. ${ }^{20} \mathrm{We}$ interviewed at least two elected city officials in each city, including council members, mayors, and representatives of local school boards. We also spoke to nonelected city officials serving on boards and commissions that work with immigrants, including the Human Relations Commissions in Fremont and Mountain View, the Santa Clara County Office of Human Relations, the San Jose Strong Neighborhood Initiative, and the Immigrant Rights Commission and the Office of Civic Engagement and Immigrant Affairs in San Francisco. Among immigrant organizations, we interviewed the executive director or another knowledgeable individual about the organization's history and activities. Interviews lasted on average from one to two hours and followed a semi-structured format.

${ }^{19}$ Their nonprofit status bans immigrant organizations from partisan electioneering, but they can advocate for members and clients and engage in limited lobbying (Berry with Arons 2005; de Graauw 2008).

${ }^{20}$ We completed 46 interviews in San Francisco, 65 in San Jose, 16 in Fremont, and 15 in Mountain View. 
American Journal of Sociology

\section{FINDINGS: CITY FUNDING AND IMMIGRANT ORGANIZATIONS}

Immigrants increasingly live in suburbs, but these new destinations are slow to respond to their foreign-born residents. As table 1 shows, a greater proportion of residents in Fremont and Mountain View are foreign-born than in the central cities, and while the two suburbs have, on average, a lower percentage of poor people than the two central cities, immigrants make up a larger proportion of the poor in the suburbs than in San Francisco and San Jose. As smaller cities, Fremont and Mountain View had less funding to allocate, making it harder to give many grants during the period of our review. Nevertheless, none of the CDBG money that suburbs awarded to nonprofits went to immigrant organizations in 2004-7, as shown in table 2. The lack of funding is especially noteworthy given that the CDBG program targets community development and services to low- and moderate-income persons. ${ }^{21}$

In contrast, over the same three years, San Francisco gave grants to 38, 40 , and 41 immigrant organizations, respectively, out of a total of 130, 151, and 124 nonprofits funded. Immigrant organizations thus accounted for between $26.5 \%$ and $33.1 \%$ of CDBG grant recipients, and they tended to receive slightly more funding, on average, than nonimmigrant organizations. Over $\$ 4$ million went to immigrant organizations in each of the years studied, which equaled $34.2 \%, 33.7 \%$, and $40.4 \%$ of all grants allocated to community organizations in 2004-5, 2005-6, and 2006-7, respectively. The funding proportions are in line with the proportion of immigrants living in San Francisco and the proportion of immigrants among the city's poor residents.

The situation in San Jose stands between that of the suburbs and San Francisco. San Jose received a smaller entitlement grant than San Francisco and allocated less CDBG money to community organizations, funding 39 groups in 2004-5, 38 in 2005-6, and 37 in 2006-7. Among grantees, seven were immigrant organizations in each funding cycle, representing $17.9 \%-18.9 \%$ of all nonprofits funded. As in San Francisco, immigrant organizations received, on average, a larger grant than nonimmigrant organizations, and the average value of grants rose over time. In 2004-5, immigrant organizations received $18.4 \%$ of funding available to nonprofits; this increased to $23.5 \%$ and $27.5 \%$ in subsequent years. The percentages are much lower than the proportion of immigrants in the general population, $39 \%$, or the percentage of immi-

\footnotetext{
${ }^{21}$ Our analysis assumes that we should expect some funding of immigrant organizations, given the composition of the poor population in suburbs. Some might challenge this assumption, expecting funding to go to umbrella organizations or groups focused on other demographic specificities: preschoolers, youth-at-risk, seniors, or the disabled, regardless of immigrant background. Under this assumption, the key empirical puzzle remains: we would need to explain why San Francisco and San Jose do nevertheless fund immigrant organizations.
} 


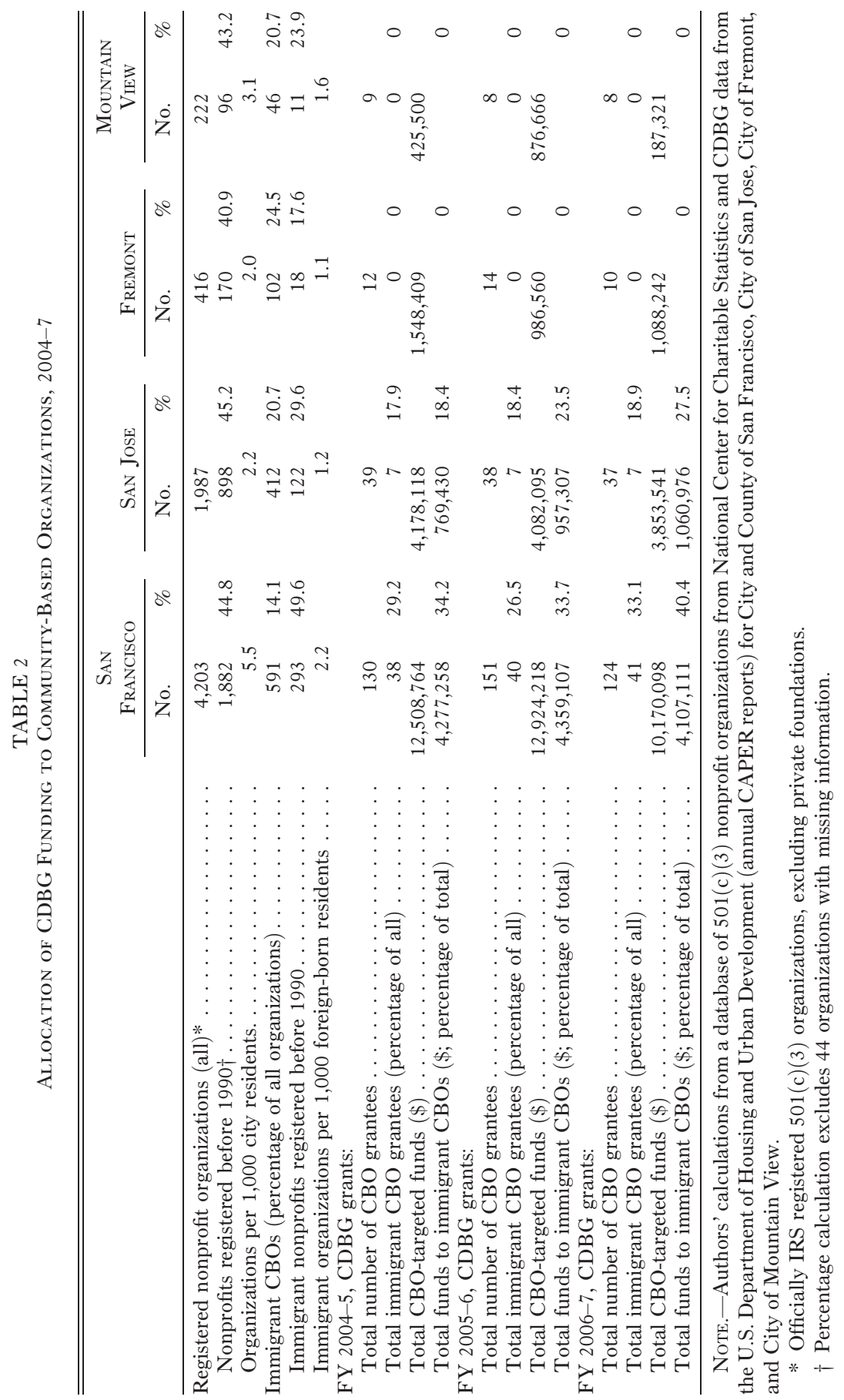


grants among the poor, $42 \%$, but we see evidence that immigrants' needs are somewhat visible to San Jose city officials who allocate and administer CDBG funds. ${ }^{22}$

One possible explanation for the funding variation could be the absence of immigrant organizations in suburban cities. However, our analysis of registered 501(c)(3) organizations shows a substantial number of organizations in each municipality, with between one and two immigrant organizations for every 1,000 foreign-born residents. While San Francisco stands out for the sheer number of registered immigrant nonprofits, at 591, these organizations constitute a smaller part of the total nonprofit universe of 4,203 organizations in the city, $14.1 \%$, than in the other three cities. In the suburbs, immigrant organizations account for $24.5 \%$ (Fremont) and $20.7 \%$ (Mountain View) of all registered nonprofits; the proportion in San Jose is the same as in Mountain View, at 20.7\%. Thus, while the density of immigrant organizations is slightly higher in San Francisco-2.2 organizations per 1,000 foreign-born residents - these immigrant organizations must compete within a much denser overall nonprofit infrastructure. For every immigrant organization in San Francisco, there are six nonimmigrant organizations; the comparable ratio is 1:3 in Fremont and 1:4 in San Jose and Mountain View. Lack of funding in suburban cities cannot be explained by an absence of immigrant organizations.

Alternatively, suburbs might not directly support immigrant nonprofits if instead they fund a few mainstream umbrella organizations that offer immigrant-targeted services. To evaluate this possibility, we investigated all grant recipients in Fremont and Mountain View and a sample of nonimmigrant grantees in San Jose and San Francisco from the list of all nonprofits that received any CDBG grant in each city during our 3-year period (see app. A). We examined whether the suburban nonimmigrant grantees were qualitatively different than their central city counterparts.

They were not. In both central cities and suburbs, some nonimmigrant organizations serve subgroups of immigrants. This is understandable given the region's demographics and nonprofits' public service orientation. Kidango, a nonprofit child development agency, is dedicated to a multicultural curriculum, integration of families of diverse economic backgrounds, and inclusion of special needs children. One branch received funding from the city of Fremont and another from San Jose. In Mountain View, an employee of the Community Services Agency, a CDBG recipient that provides emergency assistance and social services, explained that "a community needs to

${ }^{22}$ The increase in allocated monies over this period reflects the city's decision to give a few immigrant organizations significant resources for infrastructure investments: a building purchase to expand services to the Korean American community, more office space for a Japanese American group, and a grant to a Portuguese American group to renovate a kitchen used in nutritional programs. 
be welcoming of its immigrant population." The organization serves people of various ethnoracial backgrounds, and the same employee noted that Russian immigrants often work as volunteers in the food pantry. Likewise, the Ingleside Community Center in San Francisco, an organization that has long served African-Americans, more recently began outreach to the growing Chinese immigrant population in the neighborhood. Thus some suburban nonimmigrant nonprofits with CDBG grants provide services to immigrant residents. But the same is true in San Francisco and San Jose, cities that also fund immigrant-specific organizations. It is not the case that suburbs have awarded grants to special umbrella organizations with immigrant-targeted services as a distinct funding strategy.

In fact, there is substantial evidence that the service efforts of mainstream organizations are inadequate in meeting immigrant needs. Santa Clara County, which encompasses San Jose and Mountain View, conducted a needs assessment in 2000 that included a random sample of residents from the five largest immigrant groups in the county (i.e., Mexicans, Vietnamese, Chinese, Filipinos, and Indians) and a survey of public assistance beneficiaries, including the top 16 immigrant nationalities receiving public aid (Santa Clara County 2000). The two surveys found that, overall, immigrants receive only half the services that native-born residents do while they have two to four times greater need. For example, $11 \%$ of immigrants reported food insecurity compared to $3 \%$ of the native-born, yet only $47 \%$ of immigrants on public benefits received food aid compared to $72 \%$ of native-born residents (Santa Clara County 2000, pp. 95, 101). With regard to health care, native-born residents were insured at a rate 12 times higher than immigrants.

Other needs assessments have found that mainstream organizations have not invested sufficiently in multilingual and coethnic staff to serve immigrant communities adequately. In the words of one report, "Many immigrant community members, both young and old, are unaware of the health, social and legal services available to them; cannot access them due to language and cultural barriers; or are not comfortable seeking help outside of the community" (Ahuja, Gupta, and Petsod 2004, p. 13; see also Petsod, Wang, and McGarvey 2006; Santamaría and Palma 2008). The Santa Clara County needs assessment found that $64 \%$ of 36 nonprofit organizations surveyed reported that they needed to refer non-English-speaking immigrants elsewhere for services but did not know where to send them (Santa Clara County 2000, p. 104).

Thus, poverty statistics, needs assessments, and studies of nonprofits serving disadvantaged residents all show that many immigrants have human and social services needs, including those living in suburbs, but that they face inadequate community-based services. The Santa Clara County needs assessment concluded that nonprofit organizations must offer ser- 
vices "in the heart of immigrant communities"; it specifically mentioned downtown Mountain View as one ideal location. Yet in an interview, a member of Mountain View's Human Relations Commission, which oversees the CDBG allocation process, commented that among "the usual suspects that come to our meetings," the supporters of mainstream organizations - who are "for the most part, very intelligent, very well spoken"-have limited awareness of the city's diverse population. We now turn to investigate the reasons behind this disjuncture: the clear demographic presence and needs of immigrants in suburbs but a lack of public funding for immigrant organizations.

\section{UNDERSTANDING VARIATION: SUBURBAN FREE RIDING}

Lack of CDBG funding in these suburbs cannot be explained by antiimmigrant ideologies. Anti-immigrant attitudes characterize other suburban destinations (Perea 1996; Chavez 2008; Brettell and Nibbs 2011), but suburban officials in the Bay Area usually appreciate immigrants' economic contributions and cultural diversity. ${ }^{23}$ During Fremont's fiftieth anniversary celebration, programming included cricket matches and Bollywood dancing (Staff 2006). One appointed suburban official underscored that a melting pot paradigm is "unrealistic, outdated, and to some people, offensive" and proudly explained that Fremont "is in fact more diverse than many larger cities. We have people here who speak 137 different languages." In Mountain View, despite battles over day laborers' right to solicit work on public streets, every city official we interviewed spoke highly of the city's Day Worker Center. Mountain View's mayor lauded the center as not just a place for workers to meet potential employers but also one where they could receive services. "During the times that they're not working, they offer classes and that's really beneficial," he boasted. These suburbs eagerly reap the symbolic, cultural, and economic benefits of their immigrant populations and generally have a welcoming attitude toward immigrants.

Yet many suburban officials do not view immigrant organizations as partners to receive city grants. Often officials do not see immigrant organizations as part of their municipality's civic infrastructure. In some cases, immigrants and their organizations have no civic visibility at all. In other

\footnotetext{
${ }^{23}$ While many city officials have multicultural mind-sets, there are pockets of antiimmigrant sentiment among suburban residents, just like in big cities. A Fremont official recounted that when a Chinese American city councilor, born in the United States, proposed celebrating the national origins of city employees during the Fourth of July parade, "he got nasty e-mails and letters, you know, telling him to go back to the country he came from." Similarly, although Mountain View compiles a "diversity calendar" and supported May 1 immigrant rights marches, a representative of the Human Relations Commission spoke about antagonism by long-time residents toward new immigrants, including antagonism by some of the city's established Mexican American residents.
} 
cases, suburban officials acknowledge immigrants' presence but have little understanding of their needs. Or officials contend that immigrants' needs are already served by organizations in other cities. Sometimes consciously, but more often unwittingly, without calculated intent or animus, suburban officials off-load human and social service provision for immigrants to central city nonprofits, free riding off central cities' funding of services and organizations. Historically suburban residents took advantage of the jobs, transportation, and recreation in central cities but did not contribute property taxes or municipal levies to deal with urban poverty, thereby pitting suburban and urban residents against each other. The new free riding, however, produces civic and social inequalities among residents in the same suburban jurisdiction.

This occurs through a variety of processes. Some suburban officials simply know little about their city's new demographics. Such invisibility was epitomized in an interview with the executive director of a Fremont city agency that oversees nonprofit service providers. Despite her many years of experience, she recounted: "We're applying for a mental health grant to work with welfare recipients, and to our surprise one of the language requirements for our area was Vietnamese. So, we must have some folks who are out there who speak Vietnamese." This official does not have negative feelings toward immigrants; she simply does not identify immigrant residents, including thousands of Vietnamese origin, as a distinct part of the city's disadvantaged population.

In other cases, suburban officials know that immigrants live in the city, but they have not reached out to immigrant organizations. The official heading Fremont's Human Relations Commission, the government body that receives $\mathrm{CDBG}$ grant proposals and makes funding recommendations to city council, could name very few immigrant organizations. Asked about groups active in Fremont across a long list of topical areas, from arts and culture to housing and health, the official only listed one Afghan organization, a Sikh gurdwara, and a local resident active in the Muslim community. ${ }^{24}$ Similarly, in discussing the city's fiftieth anniversary event, she recounted: "We reached out to . . . business associations, to the Chamber of Commerce, to all sorts of people. We reached out to the school communities, the school districts, all the private schools, to the arts community, to all the artists, and the symphony and to the sports teams and ... to all the bunch of neighborhood groups and PTAs and crime watch." Immigrant organizations were notably absent from her list, despite the 102 officially registered immigrant organi-

${ }^{24}$ The interview schedule asked respondents to name city organizations involved in arts and music, education, health, senior citizen issues, labor unions, advocacy groups, ethnic and cultural groups, naturalization, citizenship and voting, immigrant and refugee settlement, civic clubs, neighborhood associations, housing affordability, domestic violence, public safety and emergency preparedness, veterans groups, and religious organizations. 
zations identified in the NCCS database. In a similar manner, an official on Mountain View's Human Relations Commission, which also has a mandate to evaluate and make recommendations on CDBG allocations, could not name a local group that worked with immigrants or refugees other than the Day Worker Center; NCCS data indicate that Mountain View is home to 46 registered immigrant nonprofits. ${ }^{25}$

It is not the case that suburban immigrant organizations shun partnerships with government as a matter of ideology. Our interviews, media stories (e.g., Benson 2007), and the financial reports of a few prominent suburban organizations indicate that immigrant leaders welcome funding from county, state, and federal governments. For example, the executive director of the India Community Center (ICC), located in the neighboring city of Milpitas but with senior programs in Fremont, explained that ICC has sought out government grants to support senior services, in addition to membership dues and individual and corporate donations that fund other activities. Yet immigrant organizations such as ICC repeatedly fail to appear on the suburban rolls of CDBG recipients.

This absence reflects the often contradictory perspective suburban government officials hold toward these organizations. One discourse suggests that well-organized immigrant organizations do not need government funding. A nonelected Fremont official explained, expressing admiration for ICC's activities: "Most organizations would [use a] paid position, [but] they find highly-skilled volunteers to donate their time to them. I'm very impressed with that." Organizational prowess - usually something that city officials appreciate in allocating grants-becomes a reason to not fund organizations seen as having the wherewithal to organize themselves. Conversely, a lack of organizational capacity also serves as a rationale for avoiding public-private partnerships. In considering the city's Latino population, many of whom live in low- or modest-income households, the same city official said: "We have, I'm sure, a whole labor force of undocumented workers from Mexico and Guatemala and other places, but for various reasons they don't get to organize. The places where they probably are most organized are around certain . . . Catholic churches." Seen to have limited civic infrastructure, these immigrant residents' needs are relegated to religious institutions. Even when a highly disadvantaged group does organize, there is no guarantee of CDBG funding. The Mountain View Day Worker Center, which serves an overwhelmingly Latino immigrant clientele and is one of the

\footnotetext{
${ }^{25}$ The reactions in Fremont and Mountain View can be found in other Bay Area suburbs. During an interview for a different study, an elected official in Sunnyvale - a suburb between Mountain View and San Jose - said that since "everyone is treated equally" in his city, the suburb does not "have many organizations or problems" related to what he saw as "special interest" immigrant activism. Forty-three percent of Sunnyvale's population was foreign-born in 2006.
} 
few active formal day labor centers in the South Bay, received no CDBG funding from the city of Mountain View from 2004 to 2007 despite the mayor's admiration for the group's work.

We believe that these contradictory rationales-immigrants as well organized enough not to get public funding or insufficiently organized to merit funding - arise because the social construction of target populations places immigrants outside the circle of legitimate recipients of public grants, especially in suburbs. This is done in a variety of ways. A few suburban officials and civic leaders hinted that immigrants might not be fully local residents since they retain ties to their countries of origin. As the head of a city social service agency in Fremont put it, reflecting on the suburb's immigrant population, "a lot of the sort of people who [have] come to this country recently - probably because of the Internet and business and world economy-they're here, but one foot here and one foot still in the country that they came from." Another narrative suggests that immigrant suburbanites are uniformly wealthy. A Fremont city councilor explained: "We're not dealing with the same kind of immigrant issues that most communities deal with in terms of the low-skilled workers and all of the debate that you hear now about the immigrant community. We've got one of the wealthiest immigrant populations." Silicon Valley is certainly home to high-skilled, well-off immigrants, but the parallel low-wage immigrant population often goes unnoticed. Asked specifically about the Latino population, a group with significant pockets of poverty, the same official said there was no organized presence in his city but that there seemed to be organizations in other cities that Fremont's Latinos could access.

Another discourse views immigrant concerns as particularly insular. An elected official in Fremont, predicating his remarks with, "I don't mean it [as] derogatory," went on to explain that various organizations in the lowincome Afghan community were centered on "self-help issues" and "improving their own lot . . . mostly it's for the welfare of their people. Help get them educated; help, you know, [with] citizenship." The label "their people" and the claim of insularity contrasted with the official's inclusive language regarding another group: residents associated with the CDBG-funded Senior Center. "We have a large number of active seniors," the official praised. These seniors are seen as part of the city's civic community, while the social construction of immigrant communities - as excessively transnational, rich, small, or insular - places them outside of it. Such narratives legitimize the lack of public-private partnerships, even in places such as Fremont, which has welcomed one of the largest Afghan communities in the United States.

Importantly, the arguments articulated by suburban officials occur in a regional context that feeds into rationales placing immigrant residents' needs outside the suburb's jurisdiction. It is impractical, according to a number of suburban officials, for small cities to pay for immigrant services 
given the availability of services and immigrant organizations in neighboring big city jurisdictions. A Fremont city councilor explained, discussing what he viewed as the small number of Vietnamese in his city, "Obviously, there are Vietnamese people [here], but my guess is that they probably go to San Jose for their, you know, ethnic involvements." Such arguments carry some face validity. The Vietnamese-origin population in Fremont is 5,600, compared to almost 90,000 in San Jose, and Fremont's operating budget is a fraction of that of its big city neighbor. Yet a nontrivial segment of Fremont's most disadvantaged residents speak Vietnamese. They are expected to rely on the nonprofit infrastructure in San Jose, which sits in a different county, is not connected to Fremont via the region's subway system, and is a 30-minute drive or hour bus ride away. In a similar manner, an elected official in Mountain View acknowledged, "It's certainly very visible that you have ethnic segments of the community," but given limited resources and a small city staff, the official explained that the suburb relies on volunteers to address the needs of its ethnic communities.

Appeals to economies of scale and references to services available in other jurisdictions are not used when it comes to childcare or homeless services, or for programs targeting seniors or handicapped residents, populations that received a substantial proportion of Fremont's CDBG money in the period we studied. We do not want to imply that these groups are not deserving of public grants but rather that suburban officials do not reflect on the takenfor-granted legitimacy of these groups compared to others. For example, CBO grants for seniors, serving 21,000 residents over age 65, totaled over $\$ 240,000$ in 2004-5, but no Latino organization received CDBG support, despite a Latino population of over $32,000 .{ }^{26}$ Asked explicitly about the city's Latino community, an elected Fremont official minimized the group's size by making explicit reference to other cities: "The percentage of Latinos in Fremont [is] small compared to other communities." Yet Fremont's Latino population represents $15 \%$ of all city residents - a proportion on par with San Francisco. Appeals to economies of scale - there are bigger immigrant populations in other cities with larger budgets, as well as a longer history of immigrant support services-help suburban officials account for the absence of funding in their own municipality. Immigrant services become the purview of the suburbs' larger and presumably richer municipal siblings.

Yet, paradoxically, the demographic growth of the suburbs, fed largely by immigration, has increased the size of the CDBG entitlement grants from the federal government in new destinations, but not in San Francisco. In 2004, Fremont's total CDBG grant was $85 \%$ larger than the one it re-

\footnotetext{
${ }^{26}$ The city also awarded over $\$ 250,000$ in non-CBO funding from CDBG monies to the city-run Senior Center in 2005-6.
} 
ceived in 1978; Mountain View's CDBG grant in 2004 was 38\% larger than in $1978 .{ }^{27}$ San Francisco, due to its stagnant population, received $3 \%$ less in CDBG funds in 2004 compared to 1978 . We would expect cities with growing CDBG entitlement grants to have more room to fund new groups, such as immigrant organizations.

And yet they do not. We label this phenomenon suburban free riding. It results from suburban officials' taken-for-granted ideas about suburban life - often rooted in iconic images more appropriate to earlier decadesand from assumptions about immigrants' needs arrived at without dialogue with immigrant organizations. ${ }^{28} \mathrm{~A}$ Fremont city councilor of immigrant origins, for example, described a small group of residents very active in city affairs who have "lived here forever, who [see] Fremont as a rural community and not even as a suburban community." These individuals still imagine a place with fields and a time when the city "was fairly uniform and unified." In this context, immigration and minority issues are big city problems, not those of a bedroom community. We speculate that especially in regions with long-standing immigrant gateways such as San Francisco, or even 21 st-century gateways like San Jose, the presence of central cities reinforces the notion that immigrant services are primarily big city responsibilities. $^{29}$

The staff of immigrant organizations in San Jose and San Francisco are familiar with suburban free riding. An employee of a Vietnamese organization in San Jose, which receives CDBG funds, explained that many clients and volunteers come from outside San Jose, including Fremont. A staff mem-

\footnotetext{
${ }^{27}$ San Jose benefited the most from population growth: its funding increased $92 \%$ from 1978 to 2004. We thank Leah Brooks for sharing her data set of CDBG funding across U.S. localities (see Brooks and Phillips 2008; Brooks, Phillips, and Sinitsyn 2011). Her data count a municipality's entire CDBG entitlement grant, including funding for capital projects and community organizations. We only focus on the latter.

${ }^{28} \mathrm{~A}$ community leader active in an all-Latina mothers' group and her child's PTA contended that few city officials or local civic leaders reach out to Fremont's Spanish-speaking population: "Before I was PTA President, we had two or three Caucasian people that were involved in PTA, and letters went home, but they went home in English. . . . So, by me being there, and writing . . . in English and on the other side in Spanish . . . even though there was a language barrier, the fact that I had sent the letter out in two languages ... there was a big change in [PTA] attendance."

${ }^{29}$ Suburban free riding is not always vis-à-vis big cities; a few respondents suggested neighboring suburbs took care of a particular immigrant-origin group. During an interview with an official on the Fremont Senior Citizens Commission, when asked about Portuguese-origin seniors, the official said the community is "mainly in Newark." Asked about those of Indian origin, the official pointed to programming in Milpitas. And when asked about the city's Vietnamese population, the commissioner reported not knowing any Vietnamese organizations, "I know there is a Vietnamese community, but it's not as large as some other" communities.
} 
ber with La Raza Centro Legal, a CDBG grantee organization founded to serve Hispanic immigrants in San Francisco's Mission district, commented: "We've been in the community since 1973, and we've built a reputation with the high-quality legal services we provide. . . I'd say that just under $50 \%$ of our clientele comes from San Francisco, but a majority of our clientele comes from San Mateo County. . . and as far as San Jose in the south." An employee of the Vietnamese Community Center of San Francisco, also a CDBG grantee, said that her organization traditionally served residents in the low-income Tenderloin district but now also helps Vietnamese-speaking clients from south of San Francisco and the East Bay. The widespread demand for services highlights the success and regional reputation of these organizations but also the absence of comparable immigrant-targeted services in the suburbs.

Officials in San Francisco and San Jose, like those in the suburbs, face enormous budget challenges, but they view partnerships with immigrant organizations as a productive and efficient way to address the needs of city residents. The model of productive partnership goes hand-in-hand with a strong self-image of the city as a culturally and economically diverse place. A high-level administrator in San Francisco commented: "In a place as diverse as San Francisco . . . where there is a significant immigrant and refugee population, we can't just idly stand by and ignore these people. ... Our efforts at reaching out to immigrants and refugees in this city, I think, would be a lot less effective without the various immigrant groups that we fund. We simply wouldn't be able to reach into some pockets of the immigrant community. These organizations - and they'll also tell you that they have a better ability to connect and deliver the kinds of services that immigrants need."

Officials in both central cities, but especially in San Francisco, consistently talked about the advantages of partnerships with immigrant organizations, even though immigrants constitute a smaller percentage of their overall city and poor populations than in the suburbs. San Jose and San Francisco are not able to free ride on the resources of other jurisdictions and must invest in local immigrant organizations, although they vary in the extent to which they do.

UNDERSTANDING VARIATION: A CONTINUOUS AND 21ST-CENTURY IMMIGRANT GATEWAY

San Jose and San Francisco differ from the suburbs and each other in the proportion of CDBG funding they allocate to immigrant organizations. Many more immigrant organizations in San Francisco enjoyed, collectively, a larger share of CDBG funding. These public-private partnerships occur even though immigrant organizations face resource competition from a much 
denser civil society: San Francisco counts over five 501(c)(3) organizations per 1,000 city residents, almost double the concentration of nonprofits in Mountain View and more than two times the concentration in San Jose and Fremont (see table 2). A key explanation for more equitable immigrant funding, we believe, lies in San Francisco's history of immigration. Historical legacies have produced a broad and sophisticated immigrant civic infrastructure and a normative orientation among elected and nonelected city officials that immigrants can and should make claims on city resources.

San Francisco's history as a continuous gateway has produced a diverse set of immigrant organizations with expertise, networks, and a strong sense that they are legitimate stakeholders in city affairs. Considering all registered nonprofit organizations in the four cities, 41\%-45\% acquired 501(c)(3) status before 1990 , as shown in table $2 .{ }^{30}$ Focusing only on immigrant organizations in San Francisco, 50\% are long-standing nonprofits, registered before 1990 . Roughly a dozen date back to the late 19th century, when the city experienced significant migration from China, Italy, Ireland, the Philippines, and Russia. Immigrant organizations in the other three cities are, on average, more recently registered. Even in San Jose, home to over 350,000 immigrants, only $30 \%$ of immigrant organizations were formal 501(c)(3) organizations before 1990, a much "younger" organizational profile.

An older stock of immigrant organizations helps incubate a new generation of immigrant organizations in San Francisco as the immigrant population changes. An employee of the International Institute of San Francisco (IISF) explained:

We were founded in 1918 to help early immigrants to this country, many of them from Europe. And we still do that type of service work today, but our work also lives on through a number of other organizations. . . . We founded the Chinese Newcomers Service Center in 1969. And what is now the Southeast Asian Community Center, we started that in 1976, and then we also had a hand in getting seed funding to start the Filipino Newcomer Service Center, this was also in the 1970s. ... We created these spin-offs because there was a demand for services for specific groups of immigrants and refugees, and these services at the time IISF couldn't provide or simply couldn't provide fast enough.

New organizations can build on the know-how and reputation of established groups.

Would-be leaders of new immigrant organizations, who are sometimes staff or volunteers from existing organizations, can also access an array of

\footnotetext{
${ }^{30}$ This is the date that the IRS ruled an organization a legal nonprofit, a designation necessary for CDBG funding. In many cases, organizations are founded before gaining formal charitable status.
} 
resources for leadership development and grant writing in San Francisco. An employee of the Zellerbach Family Foundation, a grant-making institution in San Francisco noted: "An organization called CompassPoint provides workshops to teach nonprofit staff leadership and management skills and also strategies to increase the impact of their advocacy. . . . Then there's Partnership for Immigrant Leadership and Action, which is . . . a nonprofit that specifically provides technical assistance to other nonprofits in lowincome immigrant communities." Thus, successive generations of immigrant organizations and an identifiable infrastructure of support groups generate knowledge, expertise, and confidence to engage local government.

Civic infrastructure is not enough, however. A continuous history of immigration also creates a normative environment where the provision of immigrant services is an accepted city practice and where immigrant organizations are visible, legitimate partners of city government. Many of the CDBG-funded immigrant organizations that we visited in San Francisco prominently displayed awards of appreciation from the Board of Supervisors and the Mayor's Office, which shows on a more symbolic level that immigrant organizations are incorporated into the city's civic fabric. The city also recognizes that disadvantaged populations can evolve as migration flows change. San Francisco's 2005-10 consolidated plan, which structures CDBG priorities, explicitly states that community development must address "the unanticipated needs of existing and emerging populations." ${ }^{11}$

In contrast, suburban officials often appear reluctant to challenge longstanding grant-making patterns. One suburban official, who participated in awarding grants, acknowledged: "You see [immigrants] in the grant process. We had the Afghan women come to us and request money. ... . [ But] we only get a certain amount [of money]. . . . You're going to take money from somewhere else to give it to them." In San Francisco, city officials acknowledge such trade-offs, but they view immigrant organizations, including newer groups, as legitimate grantees.

San Francisco officials explicitly mention that public-private partnerships leverage the linguistic skills and service work of immigrant organizations. One high-level San Francisco administrator said: "I think literally

\footnotetext{
${ }^{31}$ San Francisco's 2005-10 consolidated plan states, in its discussion of goals and its definition of community development, that "in recognition of the rapidly changing demographics and character of San Francisco, [the Mayor's Office of Community Development] will make funding available to address the unanticipated needs of existing and emerging populations/communities that cannot be addressed through our already identified strategies. During the past 25 years, this strategy has enabled San Francisco's community development program to be a national leader in using CDBG to respond quickly and effectively to the AIDS crisis, the plight of refugees and immigrants, and the challenges of creating economic access for traditionally marginalized sub-populations" (CCSF 2006, p. 63).
} 
$50 \%$ of our city's delivery of services is accomplished through nonprofits, particularly in the health field, social services, and services for the aging population. Additionally, nonprofits play a key role in identifying problems for us to solve. . . . [Immigrant organizations] should be there, because essentially they represent people who have yet to gain access to government." City officials also partner with immigrant organizations because they offer channels of communication to city residents. One supervisor spoke approvingly of the advocacy and service work of immigrant organizations: "Nonprofits briefed me and my staff ... and we recognized some startling facts, that about a quarter of San Franciscans are less than proficient in English. . . . The entire city is at potential risk if the government cannot communicate with the citizenry in times of emergency, certainly, but on an on-going basis, we have services. That is why government exists, to provide services, and if we can't communicate with a quarter to a half of our citizenry, then what are we doing?" In San Francisco, elected and nonelected officials discussed public-private partnerships in similar ways to officials interviewed by Frasure and Jones-Correa (2010) in the suburbs ringing Washington, D.C.

Leveraging nonprofits' service work is thus possible in large cities and in smaller suburbs. Our focus on the social construction of target populations helps explain, however, where and when city officials see such publicprivate partnerships as advisable. This elucidates the dynamics behind suburban free riding, and it helps explain differences in funding between a traditional immigrant gateway like San Francisco and a 21st-century gateway such as San Jose. Like suburban officials, a few San Jose councilors had a hard time naming a single immigrant or ethnic organization in the city. One councilor acknowledged that "there are [immigrant] groups who interface with the City Council to try to settle issues," but then explained, "I don't know all the names of these organizations" after having a hard time naming one. In fact, we counted 412 registered immigrant nonprofits in San Jose. Some San Jose officials, like some of their suburban counterparts, viewed relations with immigrant communities as occurring via liaisons rather than direct partnerships (Bloemraad and Gleeson 2012). A San Jose councilor talked about the importance of working with "a representative from the consulates" to address immigrants' issues. The emphasis on intermediaries rather than direct public-private partnerships and the more limited knowledge of immigrant organizations help explain why, of about 38 San Jose-based organizations funded annually through city CDBG grants from 2004 to 2007, only seven were immigrant organizations. This included only one Latino organization in a city where $31 \%$ of the population is Latino. San Francisco, where Latinos make up 14\% of the population, funded more Latino organizations, groups that city officials readily identified by name. 
Immigrant organizations in the 21st-century gateway city of San Jose have not yet achieved the experience, legitimacy, and authoritative voice to challenge such exclusions. They have, on average, shorter institutional histories since immigrants formed a much smaller proportion of the population from the 1950 s to the 1980s. The leader of a pan-Asian organization in San Jose contrasted his group's growing pains with allied, and more established, organizations in San Francisco: "It was great that we have operated for three years, but we did run across some issues within the organization that would have helped tremendously if we would have had some sort of document to go back to." Shorter institutional histories hinder immigrant advocates' ability to secure funding.

It is also harder for immigrant leaders to find adequate resources to set up and run new organizations. For example, when San Jose's Parks and Recreation Department mandated 501(c)(3) status for all organizations receiving city support, including those renting city properties, a young secondgeneration Latina who heads an Aztec dance troupe had difficulties buying insurance and learning how to file the paperwork needed to register as a nonprofit. San Jose is home to leadership development organizations, such as the San Jose Leadership Council, which provides technical assistance and training for individuals willing to pay its $\$ 2,195$ tuition bill. Given the substantial fee, its business orientation, and limited outreach to immigrants, the Leadership Council does not play a role analogous to Partnership for Immigrant Leadership and Action in San Francisco. Santa Clara County has offered an immigrant leadership course, but participation is by nomination and only a limited number of scholarships are available to low-income participants.

San Jose's sheer size-including a larger budget and more developed bureaucracy - does generate more openings for immigrant populations to partner with city officials compared to the suburbs. San Jose's Strong Neighborhood Initiative (SNI) directed redevelopment funding and staff outreach to "blighted" areas, including some immigrant neighborhoods with underdeveloped civic infrastructures. One city employee explained, "The intent [was] to reach out to everybody within the area to try to bring them to these meetings, to begin a conversation. . . . We would actually do grassroots organizing to get people to come out ... going door-to-door, talking to people, asking them what their issues were and then try to get them to come out to these community-wide meetings." Several SNI staff were multilingual, and occasionally they helped neighborhood organizations with CDBG grant applications. One SNI staff member noted that these efforts increased civic engagement by bringing more people into municipal discussions and fostered networks among participants. It also increased residents' sense of legitimacy: "They feel far more entitled, far more inclined to say, 'Hey, this is an issue our [City] Council should have had." Compared to the suburbs, 
San Jose's larger bureaucracy makes it easier for city officials to interact with, and even organize, city residents, including immigrants. This helps cultivate public-private partnerships with immigrant communities and generates a greater sense of civic inclusion on both sides.

\section{CONCLUDING DISCUSSION AND FUTURE EXTENSIONS}

The service and advocacy work of community organizations is largely conceived of as taking place in the urban core of large central cities. Yet immigration, gentrification, and new patterns of job growth have rendered suburban communities much more diverse - in socioeconomic, linguistic, racial, and cultural terms - than ever before. These same dynamics have also contributed to the rapid growth of 21st-century gateway cities. Are governments in these new destinations building partnerships with immigrant residents and their organizations, especially with those of low or modest income?

Based on comparisons of CDBG allocations in four Bay Area cities, we conclude that immigrant organizations are incorporated in the traditional immigrant gateway of San Francisco; they are partially seen, but inadequately funded, in San Jose, a 21st-century gateway; and they are invisible or ignored in the new suburban destinations of Fremont and Mountain View. In San Francisco, immigrant organizations receive a share of public resources on par with immigrants' proportion among city residents and among the poor; in San Jose, officials allocate some resources to immigrant organizations but much less than immigrants' prevalence among the poor. Most striking, in the large and smaller suburban cities of Fremont and Mountain View, no immigrant organization garnered a single dollar in CDBG funding over the three-year period we studied, even though they are home to a higher proportion of immigrant residents than the big cities and even though immigrants who face linguistic, economic, and legal hardships form a larger proportion of their poor populations - the very group CDBG grants target. For welfare state researchers, these findings parallel those of Allard, who concludes that "the amount of assistance received in a social service-based system is determined by the neighborhood in which one lives, not one's level of need" (2009, p. 36). For scholars of immigration, funding disparities support the contention that researchers must distinguish between types of immigrant-receiving jurisdictions when studying the "new geography" of immigrant settlement (Singer 2004; Frey 2006; Jones-Correa 2006; Singer et al. 2008). Our attention to public grants should also encourage scholars of immigration to examine not just individual-level integration outcomes but also community-level dynamics of incorporation such as public goods allocation to collective actors.

Beyond documenting intercity variation, we develop an argument for what accounts for these differences. We contend that San Francisco's continuous 
exposure to migration over the 20th century, as compared to the other cities' more recent experiences, has produced a vibrant civic infrastructure of immigrant organizations that have the experience, networks, and expectation that they should partner with city officials. Their expectations are, for the most part, shared by local officials, who draw on a narrative of the city as an immigrant destination and on a history of public-private partnerships to justify including immigrant organizations in social service provision.

Our research also shows that government officials in the immigrant suburbs free ride on the funding that neighboring cities provide to immigrant organizations and the services those groups deliver, even though CDBG funds are supposed to be directed to the residents of a specific city, not a region. While we might expect that smaller communities with less entrenched bureaucratic interests would be able to pivot with agility to respond to disadvantaged immigrant residents, we find no evidence of this in the Bay Area. Suburban officials explain their lack of outreach and support as stemming from capacity constraints: suburbs have less money, less staff, and less experience dealing with immigrant issues. This explains part of the difference between the suburbs and big cities - more developed bureaucratic structures in San Francisco and San Jose have played a role in facilitating partnerships with immigrant organizations - but suburban officials also use the services offered by immigrant organizations in other cities to perpetuate the lack of investment in their own jurisdictions.

Suburban officials in a politically progressive region such as the Bay Area celebrate diversity among their residents, but they employ various narrative strategies to place immigrants outside socially constructed target populations. This distinction occurs even when CDBG entitlement grants to suburbs have increased in recent decades largely as a result of immigration-driven population growth. For some suburban officials, immigrants are completely invisible. For others, they are too transnational, too rich, or too organized for public support or, conversely, they are too insular, too small, or too unorganized. Although geographers, sociologists, and scholars of urban politics increasingly highlight the rise of "ethnoburbs" and "edge gateways" as a critical frontier for immigrant integration (Li 1998; Logan et al. 2002; Price and Singer 2008), our research indicates that elected and nonelected suburban officials have not yet come to terms with their cities' changing demography even if their political ideology welcomes diversity.

Given welfare state retrenchment, the consequences for disadvantaged immigrant residents and the nonprofit organizations that serve the poor are significant. Immigrants in Silicon Valley have two to four times the service needs of native-born residents, but they are about half as likely to receive help (Santa Clara County 2000). An analysis of 250 nonprofits in the area concludes that organizations serving communities of color (most of which 
serve immigrants) had $40 \%$ less income and smaller staffs and were more dependent on volunteers than other nonprofits (LaFrance Associates 2005, p. 28). To deal with high need but inadequate resources, immigrant organizations sometimes team up with larger, more resource-rich groups. In many cases, however, they are simply unable to offer the type of services and programming that they would like or that are needed.

Some may wonder whether our results merely reflect the rational political exchange dynamics of the modern day urban machine discussed by Marwell (2004, 2007). According to such an argument, funding equity in San Francisco is driven by electoral politics, whereas suburban officials get away with free riding due to a high proportion of noncitizen immigrants. It is the case that $62 \%$ of San Francisco's immigrants are U.S. citizens, while the proportion is only $35 \%$ in Mountain View. San Jose and Fremont fall in between, with just over half of their immigrant residents holding U.S. citizenship.

We cannot rule out a role for electoral politics, but the evidence suggests that any such link is far from direct. San Francisco's legislative body, the board of supervisors, was dominated by white, native-born officials in 2006. It is not the case that San Francisco reached out to immigrant organizations thanks to a diverse local legislature or patronage-style ethnic politics. Furthermore, the proportion of naturalized immigrants who were living in poverty in San Francisco in 2006, 9\%, was lower than the proportion of poor nativeborn residents $(11 \%)$ and far below the poverty rate among noncitizen migrants (18\%). Immigrants with the greatest human and social services needs are the ones without voting rights, suggesting that a rational political exchange model cannot adequately explain variation among Bay Area cities.

Organizations representing noncitizens could, of course, exert political pressure in other ways (Okamoto and Ebert 2010; Voss and Bloemraad 2011). Several of the immigrant organizations we studied can be categorized as "hybrid organizations" that combine nonprofit service provision with volunteer efforts and advocacy (Minkoff 1995; Hasenfeld and Gidron 2005; de Graauw 2008). Sometimes such organizations help spearhead protests, letter-writing campaigns, or other nonelectoral mobilization, acting akin to social movement organizations. Future research should consider whether social movement theories can help account for variation in localities' responsiveness to immigrant residents, heeding the call by Andrews and Edwards (2004) for more cross-fertilization between scholars of the nonprofit sector, interest groups, and social movement organizations. However, grantsmaking activities such as CDBG allocations fall more squarely within regular politics and bureaucratic inclusion rather than the realm of contentious politics. Relatively few social service nonprofits actively mobilize members and clients into disruptive protest behavior, preferring instead to 
engage in insider advocacy and bureaucratic strategies (Mosley 2011; de Graauw 2012).

The story we tell might change with time, particularly in more politically progressive places or as the line between bureaucratic inclusion and contentious mobilization blurs in the face of anti-immigrant initiatives at the local and state levels. ${ }^{32}$ We only collected three years of CDBG data given substantial hurdles in securing and verifying grant information and a desire to match the financial data to the timing of our field research. Since then, Fremont and Mountain View have taken small steps to fund immigrant organizations. Fremont finally awarded the Afghan Coalition, founded in 1996, a CDBG grant in 2010-11, but it was the only immigrant organization to receive funding. Similarly, the Mountain View Day Worker Center, also founded in 1996, received a $\$ 10,000$ CDBG grant in 2007-8 and in 2008-9, but it was the only immigrant organization funded (City of Mountain View 2009, p. 21). Given a political climate that is not particularly hostile to immigrants, this suggests that funding patterns and conceptions of immigrant organizations as deserving partners might change in the region over time. Since demographic realities have changed much more quickly, however, tens of thousands of migrants remain with limited organizational sources of assistance, a situation likely replicated across the United States and perhaps in other countries.

Future studies must assess how broadly our findings hold in areas with different immigration histories and regional dynamics. There is evidence that our empirical story holds in other places, although research has focused more on establishing spatial mismatch than explaining it. In a study of community organizations serving immigrant women, Truelove (2000, p. 141) found that while only $24 \%$ of recent immigrants and $26 \%$ of established immigrants in metropolitan Toronto lived in the central city, fully $53 \%$ of immigrant service providers were located in the city of Toronto, a traditional gateway in Canada. In a study of metropolitan Chicago, over half of the suburban leaders surveyed felt that their municipality did not need assistance in developing strategies to serve immigrants and indicated no awareness of immigrant populations in their jurisdiction even though the foreignborn population across the region averages 19\% (Metropolitan Mayors Caucus 2012). Suburban free riding around traditional gateway cities is likely a widespread phenomenon, as hinted at in research on New York (Marwell 2004, 2007; Cordero-Guzmán 2005) and Los Angeles (Valenzuela 2006).

\footnotetext{
${ }^{32}$ The Mountain View Day Worker Center, which was very visible in the 2006 immigrant rights protests, received a CDBG grant in 2007-8 and 2008-9; it was the only immigrant organization in the city to do so. Their protest activities might have helped increase their civic presence and ability to secure CDBG funding.
} 
Dynamics might vary in regions where the dominant central city is not a traditional immigrant gateway, such as Washington, D.C., or Atlanta. ${ }^{33}$ In such places, elected and nonelected suburban officials might take greater leadership in exchanging public funding or technical support for privately organized service provision, as in the case of day labor centers (Fine 2006; Frasure and Jones-Correa 2010). Without a traditional gateway, immigrant suburbanites might face lower hurdles to being seen as legitimate targets of social policy. A study of nonprofits in the Washington, D.C., metropolitan region provides mixed evidence for this proposition. It found that over time more immigrant organizations were locating in the suburbs; by 2007, of 533 immigrant organizations in the region, $41 \%$ were located in Maryland, a proportion on par with the $43 \%$ of immigrant residents (de Leon et al. 2009, p. 5). Conversely, however, $24 \%$ of immigrant organizationsoften those with more financial resources - were located in Washington, D.C., but only $6 \%$ of the region's immigrants lived in the capital. Organizational leaders there recounted some stories similar to those we heard, such as the perception that all Asian migrants are rich and without service needs.

We conclude that a key obstacle for immigrants residing in municipalities outside traditional gateway cities is that they are not viewed as legitimate interlocutors and civic partners by city decision makers. Particular social constructions of immigrant residents and of the municipality-for example, as a bedroom community without needy immigrants - contribute to a lack of public-private partnerships, as does a less seasoned immigrant civic infrastructure. The growing research on new immigrant destinations should consequently move beyond simple juxtapositions between progressive and anti-immigrant locales. Instead, scholars need to consider how characteristics such as city size, immigrant history, and location in a metropolitan region affect responses to immigration, paying attention to the social construction of legitimacy — of people and organizations - and civic infrastructures. Adopting a regional approach, as we do here, illuminates how suburbs can free ride on central cities' resources. The fact that such free riding occurs in the Bay Area-an unusually progressive region with relatively generous public spending on services, an active civil society, and a very high proportion of immigrant residents - raises the possibility that free riding and a lack of investment in immigrant social services might be widespread across the United States.

\footnotetext{
${ }^{33}$ Such dynamics might also be affected by the history of nonprofit service provision to poor, native-born minorities. The four cities in our study have small African-American populations, 7\% of San Francisco's residents and 3\% in San Jose. It is possible that with a larger, long-standing African-American population, immigrants might benefit from building off the black community's civic infrastructure or, conversely, face additional competition for resources and greater challenges in modifying established social constructions of disadvantaged populations.
} 
American Journal of Sociology

\section{APPENDIX A}

TABLE A1

Community-Based Organizations Receiving CDBG Grants, Funding in Dollars, Mountain View, 2004-7

\begin{tabular}{|c|c|c|c|}
\hline CBO Grantees & FY 2004-5 & FY 2005-6 & FY 2006-7 \\
\hline Clara-Mateo Alliance Shelter. & 7,000 & 5,590 & 4,429 \\
\hline Community Services Agency. & 87,407 & 90,903 & 65,048 \\
\hline Economic and Social Opportunities. & 30,000 & 30,000 & 13,656 \\
\hline Emergency Housing Consortium. . . . . . & 16,027 & 18,786 & 89,885 \\
\hline Mayview Community Health Center. . . & 8,107 & 6,388 & 5,062 \\
\hline Mid Peninsula Housing Coalition & & 717,328 & \\
\hline Project Sentinel & & & 3,163 \\
\hline Second Harvest Food Bank & 8,459 & 4,741 & 3,757 \\
\hline Senior Adults Legal Assistance & 6,000 & 2,930 & 2,322 \\
\hline Sierra Vista I Rehabilitation . & 255,000 & & \\
\hline Social Advocates for Youth. & 7,500 & & \\
\hline Total funding . & 425,500 & 876,666 & 187,321 \\
\hline
\end{tabular}

Note.-Authors' calculations from CDBG data from the U.S. Department of Housing and Urban Development (annual CAPER reports) for City of Mountain View.

TABLE A2

Community-Based Organizations Receiving CDBG Grants, Funding in Dollars, FREMONT, 2004-7

\begin{tabular}{|c|c|c|c|}
\hline CBO Grantees & FY 2004-5 & FY 2005-6 & FY 2006-7 \\
\hline C's Child Care Development & & & 19,98 \\
\hline Bay Area Community Services, Adult & 36,701 & 36,701 & 36,701 \\
\hline BRIDGE Housing & 800,000 & 50,000 & \\
\hline California School for the Blind & & 27,561 & \\
\hline Citizens Housing Corporation & & 50,000 & \\
\hline Community Child Care Coordinating Council & 19,989 & 19,989 & \\
\hline Living. . . & 10,100 & & \\
\hline or & 7,000 & 7,000 & \\
\hline Eden Council for Hope and $\mathrm{O}$ & 31,110 & 32,666 & 34,902 \\
\hline Kidan & 200,064 & 142,443 & 87,736 \\
\hline are, Meals on Wheels & 49,972 & 72 & 49,972 \\
\hline Proj & 75,000 & 75,000 & 75,000 \\
\hline t Environments Shelter. .. & 74,042 & 40,228 & 56,228 \\
\hline A (Satellite Housing Senior) . . . . . & 144,431 & & \\
\hline Tri-City & & 155,000 & 200,000 \\
\hline Tri-City Health Center & 100,000 & 250,000 & 250,000 \\
\hline Tri-City Volunteers Facility & & & 277,714 \\
\hline he Way to Recovery Center & & & \\
\hline Total $\mathrm{f}$ & $1,548,409$ & 986,560 & $1,088,242$ \\
\hline
\end{tabular}

NotE.-Authors' calculations from CDBG data from the U.S. Department of Housing and Urban Development (annual CAPER reports) for City of Fremont. 
TABLE A3

Community-Based Organizations Receiving CDBG Grants, Funding in Dollars, SAN Jose, 2004-7

\begin{tabular}{|c|c|c|c|}
\hline \multirow[b]{2}{*}{ Immigrant organizations: } & FY 2004-5 & FY $2005-6$ & FY 2006-7 \\
\hline & & & \\
\hline Ethiopian Community Services & 6,103 & 34,297 & 30,290 \\
\hline Filipino-American Senior Opportunities & & & \\
\hline Development & 36,202 & & \\
\hline Korean American Community Center & & 241,796 & 250,000 \\
\hline rvices Agency. ... . & 333,899 & 287,011 & 253,481 \\
\hline Portuguese Organization for Social Services and & & & \\
\hline Opportunities . & 130,357 & 110,803 & 245,592 \\
\hline Santa Clara County Asian Law Alliance & & 50,269 & 44,395 \\
\hline Vietnamese & 84,043 & 76,738 & 70,211 \\
\hline Yu-Ai Kai/Japanese American Community & & & \\
\hline Senio & 92,971 & 156,393 & 67,007 \\
\hline Total funding & 769,430 & & $1,060,976$ \\
\hline Nonimmigrant organizations: & & & \\
\hline lliance $f$ & 21,72 & 0,635 & $632+3$ \\
\hline & 41 & & 12 \\
\hline $\mathrm{Ca}$ & 180 & 226 & 203,295 \\
\hline $\mathrm{Co}$ & & 20,703 & 20,703 \\
\hline 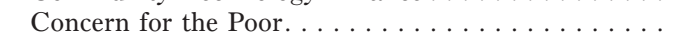 & 30,4 & & \\
\hline nd Referral Agency. . . & 29,0 & 27,588 & 27,588 \\
\hline$\ldots \ldots \ldots$ & 560 & & 00 \\
\hline$\ldots \ldots \ldots$ & 63,095 & 56 , & 50,149 \\
\hline Famil & & 28,889 & 28,889 \\
\hline ation Foundation ... & & 202,007 & \\
\hline Fres & 40,006 & 81,828 & 72,26 \\
\hline & 31, & & \\
\hline InnI & 108,606 & 103,176 & 93,875 \\
\hline & 193,287 & & \\
\hline County. & 269 & 242 & 214,257 \\
\hline & 30,496 & 28,971 & 28,971 \\
\hline$\cdots$ & 20,687 & 19,653 & 19,653 \\
\hline & 24 & & 23,583 \\
\hline Violence. & 116,882 & 121,953 & 107,701 \\
\hline Escort, Inc. . & & 45,347 & 40,048 \\
\hline & $6761+3$ & 258,833 & 228,550 \\
\hline & & & 60,000 \\
\hline r's Disease & & 29, & 29,478 \\
\hline$\ldots \ldots \ldots \ldots \ldots$ & 25,859 & 24,566 & 24,566 \\
\hline $\mathrm{S}_{\mathrm{s}}$ & 187061 & 162,830 & 149,649 \\
\hline & 208,7 & & \\
\hline lack Chamber of Commerce... & 93,920 & 90,838 & 93,920 \\
\hline & 51027 & & 26,531 \\
\hline $\mathrm{S}$ & & 101,004 & 95,131 \\
\hline & & 17,687 & 17,687 \\
\hline & 91,023 & 81,921 & 72,348 \\
\hline & 20,687 & 19,653 & 19,653 \\
\hline oration . & 287 & 278,047 & 287,481 \\
\hline iving Center. . . . . . . & 10,343 & 9,826 & 9,826 \\
\hline YWC & 175,062 & 148,803 & 131,420 \\
\hline Tot & ,408,688 & 124,788 & ,792,565 \\
\hline
\end{tabular}

Note.-Authors' calculations from CDBG data from the U.S. Department of Housing and Urban Development (annual CAPER reports) for City of San Jose. 
TABLE A4

Community-Based Organizations Receiving CDBG Grants, Funding in Dollars, San Francisco, 2004-7

\begin{tabular}{|c|c|c|c|}
\hline & FY 2004-5 & FY 2005-6 & FY 2006-7 \\
\hline \multicolumn{4}{|l|}{ Immigrant CBOs: } \\
\hline African Immigrant and Refugee Resource Center . . . & 67,000 & 77,000 & 30,000 \\
\hline Arab Cultural and Community Center . . . . . . . & 60,000 & 40,000 & 38,000 \\
\hline Arriba Juntos $\ldots \ldots \ldots \ldots \ldots \ldots \ldots$ & 38,000 & 38,000 & 110,000 \\
\hline Asian and Pacific Islander Wellness Center . . . . . & & 25,000 & 43,000 \\
\hline 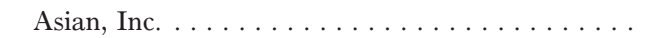 & 211,180 & 210,889 & 175,000 \\
\hline Asian Law Caucus . . . . . . . . . . . . . . . . . & 55,500 & 55,500 & 53,500 \\
\hline Asian Neighborhood Design & 391,000 & 269,000 & 292,860 \\
\hline Asian Pacific American Community Center . . . . . & 67,500 & 60,000 & 58,000 \\
\hline Asian Women's Shelter . . . . . . . . . . . . . . . . . & 39,500 & 31,500 & 35,500 \\
\hline Bindlestiff Studio . . . . . . . . . . & & 15,000 & 60,000 \\
\hline Brava! for the Women in the Arts . . . . . . . . . & 47,000 & 47,000 & 45,000 \\
\hline Career Resources Development Center. . . . . . . . . & 90,000 & 80,000 & \\
\hline Central American Resource Center (CARECEN). . . & 55,000 & 40,000 & \\
\hline Centro del Pueblo . . . . . . . . . . . . . . & & & 58,000 \\
\hline Centro Latino de San Francisco. . . . . . . . . . . . . & & & 50,000 \\
\hline Charity Cultural Services Center . . . . . . . . . & 125,000 & 100,000 & 80,000 \\
\hline Chinatown Community Development Center . . . . & 61 & & 435,000 \\
\hline Chinese for Affirmative Action. . . . . . . . . . & 110,000 & 115,000 & 100,000 \\
\hline Newcomers Service Center . . . . . . . . . . & 106,000 & 106,000 & 96,000 \\
\hline Chinese Progressive Association. . . . . . . . . . . & & & 40,000 \\
\hline Dolores Street Community Services . . . . . . . . . . & 12,000 & & \\
\hline Donaldina Cameron House . . . . . . . . . . . . & 45,000 & 115,000 & 35,000 \\
\hline of San Francisco. . . . . & 50,000 & & \\
\hline Filipino-American Development Foundation. . . . . & 205,000 & 85,000 & 190,000 \\
\hline Gum Moon Residence Hall . . . . . . . . . . . . . . . & & 15,000 & 15,000 \\
\hline Instituto Familiar de la Raza. & & & 45,000 \\
\hline$\ldots \ldots \ldots \ldots$ & 68,000 & 68,000 & 68,000 \\
\hline Japanese Community Youth Council . . . . . . . . . & & & 100,000 \\
\hline Jewish Family and Children's Services. . . . . . . . & & 67,744 & \\
\hline Career Counseling Service. . . & 81,317 & 90,300 & 60,000 \\
\hline La Casa de las I & 52,000 & & 77,000 \\
\hline La Raza Centro Legal. . . . . . . . . . . . . . . . . . & 125,000 & 125 & 115,000 \\
\hline ce Center . . . . . . . . & & 50,000 & 50,000 \\
\hline Manilatown Heritage Foundation . . . . . . . . & & 20,000 & \\
\hline evelopment Association. . . . . & 00 & 460,000 & 000 \\
\hline$\ldots \ldots \ldots \ldots$ & 131,000 & 119,000 & 162,250 \\
\hline and Vocational School, Inc. . . . & 125,000 & 275,000 & 125,000 \\
\hline Center . . . . . . . . . . & 106,5 & 00 & 75,000 \\
\hline Mission Neighborhood Centers . . . . . . . . . . & 70,000 & 205,000 & 92,000 \\
\hline Mujeres Unidas y Activas . . . . . . . . . . . . . . . & 50,000 & & 50,000 \\
\hline achi Legal Outreach . . . . . . . . . . . . . & 93,000 & 57,639 & 93,001 \\
\hline achi Little Friends. . . . . . . . . . . & 67,000 & & \\
\hline On Lok Day Services . . . . . . . . . . . . . . . . & 114,000 & 100,000 & \\
\hline $\begin{array}{l}\text { San Francisco Conservation Corps-Wu Yee- } \\
\text { Generations Child Development } \ldots \ldots \ldots \ldots\end{array}$ & & 60,000 & \\
\hline Self-Help for the Elderly $\ldots \ldots \ldots \ldots \ldots \ldots$ & 00 & 80,500 & 207,000 \\
\hline Southeast Asian Community Center . . . . . . . . . & 226,500 & 226,500 & 200,000 \\
\hline $\begin{array}{l}\text { Vietnamese Community Center of San Francisco ... } \\
\text { Vietnamese Elderly Mutual Assistance }\end{array}$ & 50,000 & 50,000 & 35,000 \\
\hline Association & 35,000 & 50,000 & 35,000 \\
\hline
\end{tabular}


TABLE A4 (Continued)

\begin{tabular}{|c|c|c|c|}
\hline & FY 2004-5 & FY 2005-6 & FY 2006-7 \\
\hline Vietnamese Youth Development Center . . . . . . . & & & 40,000 \\
\hline West Bay Pilipino Multi-Service Corp.. . . . . . . . & 95,000 & 95,000 & \\
\hline Wu Yee Children's Services . . . . . . . . . . . & 84,000 & 139,000 & 55,000 \\
\hline Total funding, immigrant CBOs. & $4,277,258$ & $4,359,107$ & $4,107,111$ \\
\hline \multicolumn{4}{|l|}{ Nonimmigrant CBOs: } \\
\hline Acorn Institute, Inc. . . . . . . . . . . . . & 50,000 & 30,000 & \\
\hline African American Art and Cultural Complex .... & 245,000 & 55,000 & \\
\hline A Home Away from Homelessness. . . . . . . . . . & & & 35,000 \\
\hline AIDS Housing Alliance . . . . . . . . . . . . . . . . & & 25,000 & 35,000 \\
\hline AIDS Legal Referral Panel of the SF Bay Area .... & 39,500 & 78,190 & 84,500 \\
\hline Arc Ecology $\ldots \ldots \ldots \ldots \ldots \ldots \ldots$ & 20,000 & 20,000 & \\
\hline Arc of San Francisco $\ldots \ldots \ldots \ldots \ldots \ldots$ & & 175,000 & \\
\hline Ark of Refuge....... & 439,364 & 12,000 & \\
\hline \multicolumn{4}{|l|}{ Bar Association of San Francisco Volunteer Legal } \\
\hline Services. . . . . . . . . . . . . . . & 30,000 & & \\
\hline Bay Area Community Resources . . & & 40,000 & \\
\hline Bay Area Legal Aid . . . . . . . . . . . . . . & 42,000 & 42,000 & 40,000 \\
\hline Bay Area Video Coalition & 100,000 & 60,000 & \\
\hline Bayview Community Collaborative . . . . . . . . & & 23,000 & \\
\hline \multicolumn{4}{|l|}{ Bayview Hunter's Point Center for Arts and } \\
\hline Technology . . . . . . . . . . . . . . . . & & 40,000 & 103,000 \\
\hline Bayview Hunters Point Multipurpose Center . . . . & & 60,000 & \\
\hline \multicolumn{4}{|l|}{ Bayview Hunters Point Multipurpose } \\
\hline Senior Services. . . . . . . & & 15,000 & \\
\hline Bernal Heights Neighborhood Center. . . . . . . . . & 248,800 & 210,000 & 215,000 \\
\hline of the Glide Foundation. . . . . . & 186,000 & 30,000 & 48,000 \\
\hline on Community Service Center. . . & 61,000 & 61,000 & 45,000 \\
\hline Boys and Girls Clubs of San Francisco ........ & 80,400 & 624,350 & \\
\hline Brothers against Guns. . . . . . . . . . . . & 55,000 & & 40,000 \\
\hline California Lawyers for the Arts . . . . . . . . . . . & & 20,000 & \\
\hline Catholic Char & 61,500 & 76,500 & 45,000 \\
\hline$\ldots \ldots \ldots$ & 92,150 & 51,650 & 31,650 \\
\hline of San Francisco .......... & 30,000 & 30,000 & 60,000 \\
\hline Clever Homes LLC. & 223,125 & 126,000 & \\
\hline \multicolumn{4}{|l|}{ Community Alliance for Special } \\
\hline Education (CASE) ....... & 25,000 & 25,000 & 25,000 \\
\hline co LGBT Community Center. . . . . . . & & 100,000 & 100,000 \\
\hline Design Center. . . . . . . . . . . . . & 155,437 & 35,000 & \\
\hline g Partnership . . . . . . . . . . & 96,085 & 122,000 & 115,000 \\
\hline ty United Against Violence . . . . . . . . . . & 27,000 & 27,000 & 27,000 \\
\hline Community Vocational Enterprises $\ldots \ldots \ldots \ldots$ & 41,500 & 51,875 & 50,000 \\
\hline \multicolumn{4}{|l|}{ Community Youth Center-San Francisco } \\
\hline$\ldots \ldots \ldots \ldots$ & 73,000 & 00 & 71,000 \\
\hline ty Services . . . . . . . . . . & 37,000 & 37,000 & 37,000 \\
\hline CompassPoint Nonprofit Services & 103,950 & 43,950 & 35,000 \\
\hline Conard House, Inc.. . . . . . . . . & 2,100 & & \\
\hline Earned Asset Resource Network (EARN) . & 25,000 & 50,000 & 50,000 \\
\hline Economic Opportunity Council of San Francisco ... & 25,000 & 15,000 & 38,000 \\
\hline Ella Hill Hutch Community Center. & 203,200 & 225,000 & 140,290 \\
\hline Episcopal Community Services of San Francisco. . . . & 30,000 & 100,000 & 100,000 \\
\hline Eviction Defense Collaborative, Inc. . . . . . . . . & & 25,000 & 30,000 \\
\hline Family School. . . . . . . . . . . & & 50,000 & \\
\hline Family Service Agency . & 226,000 & & \\
\hline Friends of the Urban Forest & & 60,000 & 40,000 \\
\hline
\end{tabular}


TABLE A4 (Continued)

FY 2004-5 FY 2005-6 FY 2006-7

Friendship House Association of American

Indians . . . . . . . . . . . . . .

Girls After School Academy. . . . . . . . . . . . . . .

Goodwill Industries of San Francisco, San Mateo,

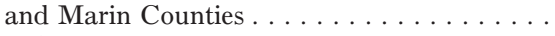

GP/Todco, Inc. . . . . . . . . . . . . . . . . . .

Growth and Learning Opportunities,

Inc. . . . . . . . . . . . . . . . .

Haight Ashbury Food Program . . . . . . . . . . .

HAPPY (Haight Ashbury Play Program

for Youth) . . . . . . . . . . . . .

Hearing and Speech Center of Northern

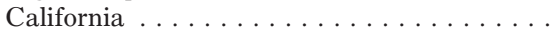

Henry Ohlhoff House . . . . . . . . . . . . . . . . . . .

Holy Family Day Home . . . . . . . . . . . . . . . . . .

Homeless Children's Network . . . . . . . . . . . . . . . .

Homeless Prenatal Program, Inc. . . . . . . . . . .

Hunter's Point Boys and Girls Club. . . . . . . . . .

Hunters Point Community Youth Park

Foundation .................

Independent Living Resource Center of San

Francisco. . . . . . . . . . . . . . . . .

Ingleside Community Center . . . . . . . . . . .

Inner City Youth $\ldots \ldots \ldots \ldots \ldots \ldots$

Iris Center . . . . . . . . . . . . .

Jamestown Community Center . . . . . . . . . . . . . . . . . . . . . . . . . . . . . . . . . . .

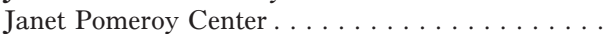

John W. King Senior Center . . . . . . . . . . . .

Juma Ventures . . . . . . . . . . . . . . . .

Larkin Street Youth Services. . . . . . . . . . . . . .

Lavender Youth Recreation and Information

Center (LYRIC) . . . . . . . . . . . . . . . . . .

Legal Assistance to the Elderly . . . . . . . . . . . . . . . .

Life Frames, Inc. . . . . . . . . . . . . . . . . . .

Literacy for Environmental Justice . . . . . . . . . . . .

Lutheran Church of Our Savior. . . . . . . . . . . .

Lyon-Martin Women's Health Services . . . . . . . .

Mission Education Projects, Inc. . . . . . . . . . . .

National Community Development Institute. . . . .

Network for Elders . . . . . . . . . . . . . . . .

New Leaf Services for Our Community . . . . . . . .

Northeast Community Federal Credit Union . . . .

Northern California Community Loan Fund . . . .

Northern California Service League. . . . . . . . . . . . . .

Opnet Community Ventures, Inc. . . . . . . . . . . . . . .

Portola Family Connections. . . . . . . . . . . . . . . . . . . . . .

Positive Resource Center . . . . . . . . . . . . . . . . . . . .

Potrero Hill Neighborhood House . . . . . . . . . . . . . .

Positive Resource Center . . . . . . . . . . . . . . . . .

Private Industry Council of San Francisco . . . . . . .

Providence Foundation . . . . . . . . . . . . . .

Rebuilding Together San Francisco . . . . . . . . . .

Recreation Center for the Handicapped . . . . . . . .

$\begin{array}{rrr} & & 36,900 \\ & 40,000 & 40,000 \\ 210,000 & & 75,000 \\ & 100,000 & 94,000 \\ & & \\ 65,000 & 27,600 & 27,600 \\ & 45,000 & 25,000\end{array}$

35,000

45,000

120,000

55,000

45,000

33,500

40,000

$30,000 \quad 20,000$

80,000

$125,000 \quad 105,000$

$\begin{array}{lll}60,000 & 60,000 & 60,000 \\ 70,500 & 63,450 & 60,000\end{array}$

$20,000 \quad 50,000$

60,000

$\begin{array}{rrr} & 50,000 & \\ & & 60,000 \\ 127,000 & 100,000 \\ 125,000 & 100,000 & 100,000 \\ 55,000 & 75,610 & 70,610 \\ 61,000 & 61,000 & 61,000 \\ & & \\ 80,000 & 66,000 & 65,000 \\ 30,000 & 30,000 & 30,000 \\ & & 50,000\end{array}$

19,000

34,000

59,900

77,500

77,500

77,500

65,000

50,000

$40,000 \quad 25,000$

37,500

58,000

63,000

50,000

55,000

55,000

55,000

195,000

230,000

$40,000 \quad 40,000$

210,000

$68,000 \quad 68,000$

66,000

50,000

100,000

$50,000 \quad 85,000$

48,000

$15,000 \quad 30,000$

115,000

70,000

90,000

41,600

15,000

70,000

20,000 
TABLE A4 (Continued)

\begin{tabular}{|c|c|c|c|}
\hline & FY 2004-5 & FY 2005-6 & FY 2006-7 \\
\hline Renaissance Entrepreneurship Center. . . . . . . . . & 436,500 & 428,500 & 350,000 \\
\hline Renaissance Parents for Success. . . . . . . . . . . & 125,000 & 100,000 & \\
\hline Richmond District Neighborhood Center . . . . . . . & 26,000 & 12,000 & 30,000 \\
\hline Sage Project $\ldots \ldots \ldots \ldots \ldots \ldots \ldots$ & 141,000 & 15,000 & \\
\hline Samoan Community Development Center . . . . . & 60,000 & 60,000 & 60,000 \\
\hline San Francisco Child Abuse Prevention Center- & & & \\
\hline $\begin{array}{r}\text { Talk . . . . . . . . . . . . . . . . . . . . . } \\
\text { San Francisco Conservation Corps-Bernal Heights }\end{array}$ & 32,500 & 32,500 & 30,000 \\
\hline State Pre-School. . . . . . . . . . . . . . . & & & 44,845 \\
\hline San Francisco Conservation Corps-Catholic & & & \\
\hline Charities-Children's Village . . . . . . . . . & & & 23,510 \\
\hline San Francisco Conservation Corps-Dr. Martin & & & \\
\hline Luther King Childcare Center. . . . . . . . . . & & 50,000 & \\
\hline San Francisco Conservation Corps-Noe Valley & & & \\
\hline Co-op Nursery . . . . . . . . . . . . . . . & & 55,000 & \\
\hline San Francisco Conservation Corps-Rainbow & & & \\
\hline Infant Center . . . . . . . . . . . . & & 64,000 & \\
\hline San Francisco Conservation Corps-Sojourner & & & \\
\hline Truth Child Care . . . . . . . . . . . . . . & & 40,000 & 54,544 \\
\hline San Francisco Conservation Corps-Whitney & & & \\
\hline Young CDC $\ldots \ldots \ldots \ldots \ldots \ldots$ & & & 34,592 \\
\hline San Francisco Foundation Community Initiative & & & \\
\hline Funds/SFFSN & & & 20,000 \\
\hline San Francisco Housing Development & & & \\
\hline Corporation $\ldots \ldots \ldots \ldots \ldots \ldots \ldots$ & & 250,000 & 100,000 \\
\hline San Francisco Lighthouse $\ldots \ldots \ldots \ldots \ldots$ & & & 25,000 \\
\hline San Francisco Parents Who Care. . . . . . . . . . & & 15,000 & \\
\hline San Francisco Study Center. . . . . . . . . . . & 20,000 & & 410,000 \\
\hline Somarts Cultural Center (with partners) . . . . . . & & 25,000 & 70,000 \\
\hline South of Market Foundation . . . . . . . . . . & 100,000 & 100,000 & 100,000 \\
\hline Southwest Community Corporation . . . . . . . & 120,000 & 66,500 & 88,000 \\
\hline St. John's Educational Thresholds Center & 25,500 & 25,500 & \\
\hline $\begin{array}{l}\text { St. Vincent de Paul Society of San Francisco . . . . } \\
\text { Sunset District Community Development }\end{array}$ & 45,000 & 45,000 & 45,000 \\
\hline Corporation. $\ldots \ldots \ldots \ldots \ldots \ldots \ldots$ & 70,000 & 75,000 & \\
\hline $\begin{array}{l}\text { Sunset Youth Services. . . . . . . . . . . . . . . } \\
\text { Swords to Ploughshares Veterans Rights }\end{array}$ & & & 50,000 \\
\hline Organization $\ldots \ldots \ldots \ldots \ldots \ldots \ldots$ & 40,000 & 40,000 & 40,000 \\
\hline Telegraph Hill Neighborhood Association . . . . . . & 125,000 & 102,000 & 30,000 \\
\hline Tenderloin AIDS Resource Center . . . . . . . . . . & 10,000 & & \\
\hline Tenderloin Housing Clinic, Inc. . . . . . . . . . . & 87,500 & 87,500 & 87,500 \\
\hline Tenderloin Neighborhood Development & & & \\
\hline Corporation $\ldots \ldots \ldots \ldots \ldots \ldots$ & 358,000 & 288,000 & 271,000 \\
\hline Tides Center. . . . . . . . . . . . . . . & 89,000 & 361,361 & 284,361 \\
\hline Together United Recommitted Forever & & & \\
\hline (T.U.R.F.) $\ldots \ldots \ldots \ldots \ldots$ & 15,000 & 50,000 & 50,000 \\
\hline Toolworks $\ldots \ldots \ldots \ldots \ldots \ldots \ldots \ldots \ldots$ & 47,000 & 47,000 & 56,085 \\
\hline United Council of Human Services. & & 58,575 & \\
\hline Urban Housing and Development Corporation... & & 25,000 & 50,000 \\
\hline Urban Resource Systems . . . . . . . . . . . & 34,000 & & \\
\hline Urban University . . . . . . . . . . . . & & 50,000 & 50,000 \\
\hline URSA Institute. . . . . . & & 25,000 & \\
\hline Visitacion Valley Community Center, Inc. . & 54,000 & 203,000 & \\
\hline
\end{tabular}


TABLE A4 (Continued)

\begin{tabular}{|c|c|c|c|}
\hline & FY 2004-5 & FY 2005-6 & FY 2006-7 \\
\hline \multicolumn{4}{|l|}{ Visitacion Valley Community Development } \\
\hline 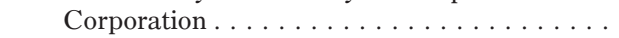 & 271,000 & 266,000 & \\
\hline Visitacion Valley JET . . . . . . . . . . . . . & 100,000 & 90,000 & \\
\hline \multicolumn{4}{|l|}{ Volunteer Center Serving San Francisco and } \\
\hline San Mateo Counties . . . . . . . . . . . . . . & 29,600 & 29,600 & \\
\hline Walden House $\ldots \ldots \ldots \ldots \ldots \ldots$ & & & 16,000 \\
\hline Westside Community Services . . . . . . . . . & & 45,000 & 30,000 \\
\hline Women's Foundation of California . . & & 85,000 & 35,000 \\
\hline Women's Initiative for Self Employment . . . . . . & 100,000 & 100,000 & 100,000 \\
\hline YMCA of San Francisco-Chinatown . . . . & 115,000 & & \\
\hline YMCA of San Francisco-Richmond. . . . . . . . & 67,600 & 11,000 & \\
\hline Young Community Developers . . . . . . . . . . & 218,595 & 75,000 & 73,000 \\
\hline Total funding, nonimmigrant CBOs . & $8,231,506$ & $8,565,111$ & $6,062,987$ \\
\hline
\end{tabular}

Note.-Authors' calculations from CDBG data from the U.S. Department of Housing and Urban Development (annual CAPER reports) for City and County of San Francisco.

\section{REFERENCES}

ABAG (Association of Bay Area Governments). 2011. Bay Area Census: San Francisco Bay Area. http://www.bayareacensus.ca.gov/cities/cities.htm.

Ahuja, Sarita, Pronita Gupta, and Daranee Petsod. 2004. Arab, Middle Eastern, Muslim and South Asian Communities in the San Francisco Bay Area. Sebastopol: Grantmakers Concerned with Immigrants and Refugees and Asian Americans/Pacific Islanders in Philanthropy.

Alba, Richard D., and John R. Logan. 1991. "Variations on Two Themes: Racial and Ethnic Patterns in the Attainment of Suburban Residence." Demography 28 (3): 431-53.

Alba, Richard D., John R. Logan, Brian J. Stults, Gilbert Marzan, and Wenquan Zhang. 1999. "Immigrant Groups in the Suburbs: A Reexamination of Suburbanization and Spatial Assimilation." American Sociological Review 64 (3): 446-60.

Allard, Scott. 2009. Out of Reach: Place, Poverty and the New American Welfare State. New Haven, Conn.: Yale University Press.

Andersen, Kristi. 2010. New Immigrant Communities: Finding a Place in Local Politics. Boulder, Colo.: Lynne Rienner.

Andrews, Kenneth T., and Bob Edwards. 2004. "Advocacy Organizations in the U.S. Political Process.” Annual Review of Sociology 30:479-506.

Baldassare, Mark. 1992. "Suburban Communities." Annual Review of Sociology 18: 475-94.

Beito, David T. 2000. From Mutual Aid to the Welfare State: Fraternal Societies and Social Services, 1890-1967. Chapel Hill: University of North Carolina Press.

Benson, Heidi. 2007. "Aging's No Fun, and It's Harder for Immigrants." San Francisco Chronicle. September 20, p. A-1.

Berry, Jeffrey M., with David F. Arons. 2005. A Voice for Nonprofits. Washington, D.C.: Brookings Institution.

Bloemraad, Irene. 2005. "The Limits of de Tocqueville: How Government Facilitates Organizational Capacity in Newcomer Communities." Journal of Ethnic and Migration Studies 31 (5): 865-87.

2006. Becoming a Citizen: Incorporating Immigrants and Refugees in the United States and Canada. Berkeley: University of California Press.

Bloemraad, Irene, and Shannon Gleeson. 2012. "Making the Case for Organizational Presence: Civic Inclusion, Access to Resources, and Formal Community Organiza- 
tions.” Pp. 109-34 in Remaking Urban Citizenship: Organizations, Institutions, and the Right to the City, edited by Michael Peter Smith and Michael McQuarrie. Comparative Urban and Community Research, vol. 10. New Brunswick, N.J.: Transaction.

Bloemraad, Irene, and Els de Graauw. 2012. "Immigrant Integration and Policy in the United States: A Loosely Stitched Patchwork." Pp. 205-32 in International Perspectives: Integration and Inclusion, edited by John Biles and James Frideres. Queen's Policy Studies Series. Montreal: McGill-Queen's University Press.

Boris, Elizabeth T., Erwin de Leon, Katie L. Roeger, and Milena Nikolova. 2010. Human Service Nonprofits and Government Collaboration Findings from the $2010 \mathrm{Na}$ tional Survey of Nonprofit Government Contracting and Grants. Washington, D.C.: Urban Institute.

Boris, Elizabeth T., and C. Eugene Steuerle. 2006. "Scope and Dimensions of the Nonprofit Sector." Pp. 66-88 in The Nonprofit Sector: A Research Handbook, edited by Walter W. Powell and Richard Steinberg. New Haven, Conn.: Yale University Press.

Boyd, Eugene. 2011. Community Development Block Grants: Funding Issues in the 112th Congress and Recent Funding History. Washington, D.C.: Congressional Research Service.

Brettell, Caroline B., and Faith G. Nibbs. 2011. "Immigrant Suburban Settlement and the 'Threat' to Middle Class Status and Identity: The Case of Farmers Branch, Texas." International Migration 49 (1): 1-30.

Brettell, Caroline B., and Deborah Reed-Danahay. 2012. Civic Engagements: The Citizenship Practices of Indian and Vietnamese Immigrants. Stanford, Calif.: Stanford University Press.

Brooks, Leah, and Justin H. Phillips. 2008. "An Institutional Explanation for the Stickiness of Federal Grants.” Journal of Law, Economics, and Organization 26 (2): 243-64.

Brooks, Leah, Justin Phillips, and Maxim Sinitsyn. 2011. "The Cabals of a Few or the Confusion of a Multitude: The Institutional Trade-off between Representation and Governance." American Economic Journal: Economic Policy 3 (1): 1-24.

Browning, Rufus P., Dale R. Marshall, and David H. Tabb. 1984. Protest Is Not Enough: The Struggle of Blacks and Hispanics for Equality in Urban Politics. Berkeley and Los Angeles: University of California Press.

CCSF (City and County of San Francisco). 2006. "San Francisco Consolidated Plan, 2005-2010." San Francisco: Mayor's Office of Housing. http://sf-moh.org/Modules /ShowDocument.aspx?documentid $=375$.

Chavez, Leo R. 2008. The Latino Threat: Constructing Immigrants, Citizens, and the Nation. Stanford, Calif.: Stanford University Press.

Child, Curtis D., and Kirsten A. Grønbjerg. 2007. "Nonprofit Advocacy Organizations: Their Characteristics and Activities." Social Science Quarterly 88 (1): 259-81.

City of Mountain View. 2009. "2008-2009 Action Plan, Revised." http://www.ci.mtnview .ca.us/civica/filebank/blobdload.asp?BlobID $=5790$.

City of San Jose. 2009. "Strong Neighborhoods Initiative." http://www.strongneighbor hoods.org/.

Cordero-Guzmán, Héctor. 2005. "Community-Based Organisations and Migration in New York City.” Journal of Ethnic and Migration Studies 31 (5): 889-909.

Cortés, Michael. 1998. "Counting Latino Nonprofits: A New Strategy for Finding Data." Nonprofit and Voluntary Sector Quarterly 27 (4): 437-58.

Dahl, Robert A. 1961. Who Governs? Democracy and Power in an American City. New Haven, Conn.: Yale University Press.

Danziger, Sandra K. 2010. "The Decline of Cash Welfare and Implications for Social Policy and Poverty." Annual Review of Sociology 35:523-45.

de Graauw, Els. 2008. "Nonprofit Organizations: Agents of Immigrant Political Incorporation in Urban America." Pp. 323-50 in Civic Hopes and Political Realities: Com- 


\section{American Journal of Sociology}

munity Organizations and Political Engagement among Immigrants in the United States and Abroad, edited by S. Karthick Ramakrishnan and Irene Bloemraad. New York: Russell Sage Foundation.

. 2012. "The Inclusive City: Public-Private Partnerships and Immigrant Rights in San Francisco.” Pp. 135-50 in Remaking Urban Citizenship: Organizations, Institutions, and the Right to the City, edited by Michael Peter Smith and Michael McQuarrie. Comparative Urban and Community Research, vol. 10. New Brunswick, N.J.: Transaction.

De Vita, Carol J., Katie L. Roeger, and Max Niedzwiecki. 2009. "Measuring Racial-Ethnic Diversity in California's Nonprofit Sector.” Washington, D.C.: Urban Institute.

Dolan, Jay P. 1975. The Immigrant Church: New York's Irish and German Catholics, 1815-1865. Baltimore: Johns Hopkins University Press.

LaFrance Associates. 2005. The 2005 Santa Clara County Nonprofit Benchmark Study. Santa Clara: Community Foundation Silicon Valley and Compass Point Nonprofit Services.

Fine, Janice. 2006. Worker Centers: Organizing Communities at the Edge of the Dream. Ithaca, N.Y.: Cornell University Press.

Frasure, Lorrie A., and Michael Jones-Correa. 2010. "The Logic of Institutional Interdependency: The Case of Day Laborer Policy in Suburbia." Urban Affairs Review 45 (4): 451-82.

Frey, William H. 2006. Diversity Spreads Out: Metropolitan Shifts in Hispanic, Asian, and Black Populations since 2000. Washington, D.C.: Brookings Institution.

Gainsborough, Juliet F. 2001. Fenced Off: The Suburbanization of American Politics. Washington, D.C.: Georgetown University Press.

Gans, Herbert J. 2009. "Some Problems of and Futures for Urban Sociology: Toward a Sociology of Settlements." City and Community 8 (3): 211-19.

Gibson, Campbell, and Kay Jung. 2006. "Historical Census Statistics on the ForeignBorn Population of the United States, 1850-2000.” Working paper no. 81. U.S. Bureau of the Census, Population Division, Washington, D.C.

Gleeson, Shannon. 2008. "Organizing for Latino Immigrant Labor Rights in Two U.S. Cities: The Case of San Jose and Houston." Pp. 107-33 in Civic Hopes and Political Realities: Immigrants, Community Organizations, and Political Engagement, edited by S. Karthick Ramakrishnan and Irene Bloemraad. New York: Russell Sage Foundation.

Gleeson, Shannon, and Irene Bloemraad. 2012. "Assessing the Scope of Immigrant Organizations: Official Undercounts and Actual Underrepresentation." Nonprofit and Voluntary Sector Quarterly 42 (2): 344-68.

Grønbjerg, Kirsten. 2001. "The U.S. Nonprofit Human Service Sector: A Creeping Revolution." Nonprofit and Voluntary Sector Quarterly 30 (2): 276-97.

Handley, Donna Milam, and Michael Howell-Moroney. 2010. "Ordering Stakeholder Relationships and Citizen Participation: Evidence from the Community Development Block Grant Program." Public Administration Review (July-August): 601-9.

Hasenfeld, Yeheskel, and Benjamin Gidron. 2005. "Understanding Multi-purpose Hybrid Voluntary Organizations: The Contributions of Theories on Civil Society, Social Movements and Non-profit Organizations.” Journal on Civil Society 1 (2): 97-112.

Hero, Rodney E. 1990. "Hispanics in Urban Government and Politics: Some Findings, Comparisons and Implications.” Western Political Quarterly 43 (2): 403-14.

Hill, Richard Child. 1974. "Separate and Unequal: Governmental Inequality in the Metropolis." American Political Science Review 68 (4): 1557-68.

Hopkins, Daniel J. 2010. "Politicized Places: Explaining Where and When Immigrants Provoke Local Opposition.” American Political Science Review 104 (1): 40-60.

Hung, Chi-Kan Richard. 2007. "Immigrant Nonprofit Organizations in U.S. Metropolitan Areas." Nonprofit and Voluntary Sector Quarterly 36 (4): 707-29. 
Iceland, John, and Kyle Anne Nelson. 2008. "Hispanic Segregation in Metropolitan America: Exploring the Multiple Forms of Spatial Assimilation." American Sociological Review 73 (5): 741-65.

Jones-Correa, Michael. 2006. "Reshaping the American Dream: Immigrants and the Politics of the New Suburbs." Pp. 75-101 in The New Suburban History, edited by Kevin M. Kruse and Thomas J. Sugrue. Chicago: University of Chicago Press.

- 2008. "Race to the Top? The Politics of Immigrant Education in Suburbia." Pp. 308-40 in New Faces in New Places: The Changing Geography of American Immigration, edited by Douglas S. Massey. New York: Russell Sage Foundation.

Kasarda, John D. 1972. "The Impact of Suburban Population Growth on Central City Service Functions." American Journal of Sociology 77 (6): 1111-24.

Katz, Michael B. 1990. The Undeserving Poor: From the War on Poverty to the War on Welfare. New York: Pantheon.

Kneebone, Elizabeth. 2010. "The Great Recession and Poverty in Metropolitan America." Washington, D.C.: Brookings Institution.

Kneebone, Elizabeth, and Alan Berube. 2013. Confronting Suburban Poverty in America. Washington, D.C.: Brookings Institution Press.

Kneebone, Elizabeth, and Emily Garr. 2010. "The Suburbanization of Poverty: Trends in Metropolitan America, 2000-2008." Washington, D.C.: Brookings Institution.

de Leon, Erwin, Matthew Maronick, Carol J. De Vita, and Elizabeth T. Boris. 2009. Community-Based Organizations and Immigrant Integration in the Washington, DC, Metropolitan Area. Washington, D.C.: Urban Institute.

Li, Wei. 1998. "Anatomy of a New Ethnic Settlement: The Chinese Ethnoburb in Los Angeles." Urban Studies 35 (3): 479-501.

Logan, John R., Richard D. Alba, and Wenquan Zhang. 2002. "Immigrant Enclaves and Ethnic Communities in New York and Los Angeles." American Sociological Review 67 (2): 299-322.

Martin, Nina. 2012. "'There Is Abuse Everywhere': Migrant Nonprofit Organizations and the Problem of Precarious Work." Urban Affairs Review 48 (3): 389-416.

Martinez, Ramiro, Jr., and Abel Valenzuela Jr., eds. 2006. Immigration and Crime: Race, Ethnicity, and Violence. New York: New York University Press.

Marrow, Helen B. 2011. New Destination Dreaming: Immigration, Race, and Legal Status in the Rural American South. Stanford, Calif.: Stanford University Press.

Marwell, Gerald, and Ruth E. Ames. 1979. "Experiments on the Provision of Public Goods: I. Resources, Interest, Group Size, and the Free-Rider Problem.” American Journal of Sociology 84 (6): 1335-60.

Marwell, Nicole P. 2004. "Privatizing the Welfare State: Nonprofit Community-Based Organizations as Political Actors.” American Sociological Review 69 (2): 265-91.

. 2007. Bargaining for Brooklyn: Community Organizations in the Entrepreneurial City. Chicago: University of Chicago Press.

Massey, Douglas S. 1985. "Ethnic Residential Segregation: A Theoretical Synthesis and Empirical Review." Sociology and Social Research 69 (3): 315-50.

Massey, Douglas S., and Nancy A. Denton. 1988. "Suburbanization and Segregation in U.S. Metropolitan Areas." American Journal of Sociology 94 (3): 592-626.

Metropolitan Mayors Caucus. 2012. Immigrant Integration in Chicago's Suburbs: A Survey of Current Activities and Efforts. http://www.cleanaircounts.org/documents /DTF\%20GUIDEBOOK\%20FINAL.pdf.

Minkoff, Debra C. 1995. Organizing for Equality: The Evolution of Women's and RacialEthnic Organizations in America, 1955-1985. New Brunswick, N.J.: Rutgers University Press.

. 1997. "The Sequencing of Social Movements." American Sociological Review 62 (5): 779-99. 


\section{American Journal of Sociology}

Mosley, Jennifer E. 2011. "Institutionalization, Privatization, and Political Opportunity: What Tactical Choices Reveal about the Policy Advocacy of Human Service Nonprofits." Nonprofit and Voluntary Sector Quarterly 40 (3): 435-57.

National Center for Charitable Statistics (NCCS). 2005. "DD Revenue and Expenses v2005b." Washington, D.C.: Urban Institute.

Newton, Lina. 2008. Illegal, Alien, or Immigrant: The Politics of Immigration Reform. New York: New York University Press.

Okamoto, Dina, and Kim Ebert. 2010. "Beyond the Ballot: Immigrant Collective Action in Gateways and New Destinations in the United States.” Social Problems 57 (4): 529-58.

Oliver, J. Eric. 2001. Democracy in Suburbia. Princeton, N.J.: Princeton University Press.

Olson, Mancur. 1965. The Logic of Collective Action. Cambridge, Mass.: Harvard University Press.

Panchok-Berry, Andrea, Alejandro Rivas, and Alexandra Murphy. 2011. "Living Just Enough for the Suburbs? The Landscape of Immigrant Resources in the City and Suburbs of Philadelphia." Paper presented at the Suburbs and the 2010 Census Conference. George Mason University, Arlington, Va.

Park, Robert E. 1926. "The Urban Community as a Spatial Pattern and a Moral Order." Pp. 3-18 in The Urban Community, edited by Ernest W. Burgess. Chicago: University of Chicago Press.

Pastor, Manuel, T. William Lester, and Justin Scoggins. 2009. "Why Regions? Why Now? Who Cares?" Journal of Urban Affairs 31 (3): 269-96.

Perea, Juan F. 1996. Immigrants Out! The New Nativism and the Anti-immigrant Impulse in the United States. New York: New York University Press.

Petsod, Daranee, Ted Wang, and Craig McGarvey. 2006. Investing in Our Communities: Strategies for Immigrant Integration. Sebastopol: Grantmakers Concerned with Immigrants and Refugees.

Price, Marie, and Audrey Singer. 2008. "Edge Gateways: Immigrants, Suburbs, and the Politics of Reception in Metropolitan Washington." Pp. 137-68 in Twenty-First Century Gateways: Immigrant Incorporation in Suburban America, edited by Audrey Singer, Susan W. Hardwick, and Caroline B. Brettell. Washington, D.C.: Brookings Institution.

Puentes, Robert, and David Warren. 2006. "One Fifth of the Nation: A Comprehensive Guide to America's First Suburbs.” Washington, D.C.: Brookings Institution.

Ramakrishnan, S. Karthick, and Irene Bloemraad, eds. 2008. Civic Hopes and Political Realities: Immigrants, Community Organizations, and Political Engagement. New York: Russell Sage Foundation.

Ramakrishnan, S. Karthick, and Paul G. Lewis. 2005. Immigrants and Local Governance: The View from City Hall. San Francisco: Public Policy Institute of California.

Ramakrishnan, S. Karthick, and Tom Wong. 2010. "Partisanship, Not Spanish: Explaining Municipal Ordinances Affecting Undocumented Immigrants.” Pp. 73-93 in Taking Local Control: Immigration Policy Activism in U.S. Cities and States, edited by Monica W. Varsanyi. Stanford, Calif.: Stanford University Press.

Reckhow, Sarah, and Margaret Weir. 2012. "Building a Resilient Social Safety Net." Pp. 275-323 in Urban and Regional Policy and Its Effects: Building Resilient Regions, vol. 4. Edited by Margaret Weir, Nancy Pindus, Howard Wial, and Harold Wolman. Washington, D.C.: Brookings Institution.

Rich, Michael J. 1993. Federal Policymaking and the Poor: National Goals, Local Choices, and Distributional Outcomes. Princeton, N.J.: Princeton University Press.

Rimmerman, Craig. 1985. "Citizen Participation and Policy Implementation in the Columbus, Ohio CDBG Program.” Public Administration Quarterly 9 (3): 328-41.

Rosenfeld, Raymond A., Laura A. Reese, and Vicky Georgeau. 1995. "Community Development Block Grant Spending Revisited: Patterns of Program and Benefit Institutionalization." Publius: The Journal of Federalism 25 (4): 55-72. 
Salamon, Lester M. 1999. America's Nonprofit Sector: A Primer. New York: Foundation Center.

2003. The Resilient Sector: The State of Nonprofit America. Washington, D.C.: Brookings Institution.

San Jose City Council. 2007. "Resolution No. 73677: A Resolution of the Council of the City of San Jose Supporting Public Safety and Immigrant Rights." San Jose, Calif.

Santa Ana, Otto. 2002. Brown Tide Rising: Metaphors of Latinos in Contemporary American Public Discourse. Austin: University of Texas Press.

Santa Clara County Office of Human Relations. 2000. Bridging Borders in Silicon Valley: Summit on Immigrant Needs and Contributions. San Jose, Calif.: Santa Clara County Office of Human Relations, Citizenship and Immigrant Services Program.

Santamaría, Manuel J., and Mauricio Palma. 2008. Immigrant Integration in Silicon Valley: Legalization, Language Acquisition and Bridging the Cultural Gap. Mountain View, Calif.: Silicon Valley Community Foundation.

Schneider, Anne, and Helen Ingram. 1993. "Social Construction of Target Populations: Implications for Politics and Policy." American Political Science Review 87 (2): 334-47.

Schneider, Anne, and Mara Sidney. 2009. "What Is Next for Policy Design and Social Construction Theory?" Policy Studies Journal 37 (1): 103-19.

Singer, Audrey. 2004. "The Rise of New Immigrant Gateways.” Living Cities Census Series. Washington, D.C.: Center on Urban and Metropolitan Policy, Brookings Institution.

- 2008. "Twenty-First-Century Gateways: An Introduction." Pp. 3-30 in TwentyFirst Century Gateways: Immigrant Incorporation in Suburban America, edited by Audrey Singer, Susan W. Hardwick, and Caroline Brettell. Washington, D.C.: Brookings Institution.

Singer, Audrey, Susan W. Hardwick, and Caroline Brettell, eds. 2008. Twenty-First Century Gateways: Immigrant Incorporation in Suburban America. Washington, D.C.: Brookings Institution.

Small, Mario Luis. 2009. Unanticipated Gains: Origins of Network Inequality in Everyday Life. New York: Oxford University Press.

Smith, Steven Rathgeb, and Michael Lipsky. 1993. Nonprofits for Hire: The Welfare State in the Age of Contracting. Cambridge, Mass.: Harvard University Press.

Staff. 2006. "Celebrate Fremont." Tri-City Voice, September 5.

Sterne, Evelyn Savidge. 2001. "Beyond the Boss: Immigration and American Political Culture from 1880 to 1940." Pp. 33-66 in E Pluribus Unum? Contemporary and Historical Perspectives on Immigrant Political Incorporation, edited by Gary Gerstle and John H. Mollenkopf. New York: Russell Sage Foundation.

Tanenbaum, Molly. 2006. "Reflecting on the March: For First Time, Latinos Sense Power of Numbers." Mountain View Voice, May 12.

Trolander, Judith Ann. 1987. Professionalism and Social Change: From the Settlement House Movement to Neighborhood Centers, 1886 to the Present. New York: Columbia University Press.

Truelove, Marie. 2000. "Services for Immigrant Women: An Evaluation of Locations." Canadian Geographer, 44 (2): 135-51.

U.S. Census Bureau. 2009. “2005-2007 American Community Survey 3-Year Estimates, Custom Table." American Factfinder. Washington, D.C.

_. 2011. "2010 American Community Survey 1-Year Estimate, Table DP02”. http:// factfinder2.census.gov.

Valenzuela, Abel, Jr. 2006. Identifying and Assessing Immigrant-Serving Organizations: Los Angeles and Orange County. Report prepared for the Rockefeller Foundation.

Voss, Kim, and Irene Bloemraad, eds. 2011. Rallying for Immigrant Rights: The Fightfor Inclusion in the 21st Century. Berkeley and Los Angeles: University of California Press. 


\section{American Journal of Sociology}

Waldinger, Roger. 1989. "Immigration and Urban Change." Annual Review of Sociology 15 (1): 211-32.

Walker, Edward T., and John D. McCarthy. 2010. "Legitimacy, Strategy, and Resources in the Survival of Community-Based Organizations." Social Problems 57 (3): 315-40.

Weir, Margaret, Nancy Pindus, Howard Wial, and Harold Wolman, eds. 2012. Urban and Regional Policy and Its Effects: Building Resilient Regions, vol. 4. Washington, D.C.: Brookings Institution.

Wright, Richard, Mark Ellis, and Virginia Parks. 2005. "Re-placing Whiteness in Spatial Assimilation Research." City and Community 4 (2): 111-35. 